\title{
Journal of Law, Public Policies and Human Sciences
}

Volume 2 - Issue 2 - April 2021

EDITORIAL

\author{
RESUMO DO CONTATO COM O DR. MARIK. MEDICINA PULMONAR E DE \\ CUIDADOS CRÍTICOS. ESCOLA MÉDICA DA VIRGÍNIA ORIENTAL - EUA.
}

\author{
SUMMARY OF CONTACT WITH DR. MARIK. PULMONARY MEDICINE AND CRITICAL \\ CARE. EASTERN VIRGINIA MEDICAL SCHOOL - USA.
}

\author{
Luis Alcides Brandini De Boni, Ph.D. \\ JLPPHS, Brazil. \\ * Corresponding author \\ e-mail: jlpphs@gmail.com
}

\section{EDITORIAL}

Esta breve nota introduz a reprodução de conteúdo medico, de autoria do Doutor Paul E. Marik. O Dr. Marik é Professor de Medicina e Chefe de Medicina Pulmonar e de Cuidados Críticos da Eastern Virginia Medical School em Norfolk, Virginia (EUA). Dr. Marik é um profissional extremamente qualificado e experiente. A reimpressão do material foi autorizada pelo próprio Dr. Marik em 02/12/2020. Este material é relevante no cenário Brasileiro pela proposição de procedimentos padronizados aos pacientes contaminados pelo corona vírus. Foi selecionado apenas 1 dos 5 arquivos gentilmente cedidos pelo autor, em formato PDF, e reproduzido na forma como foi recebido, sem qualquer edição. Devido ao amplo período de duração da pandemia, os editores do Jornal (que não são médicos) já tiveram a oportunidade de acompanhar o desenvolvimento da doença em mais de uma pessoa infectada. O tipo de tratamento oferecido aos pacientes parece influenciar no curso, duração e severidade da doença. Os tratamentos descritos nos materiais a seguir, parecem ser eficazes e com bons resultados. Visando não influenciar ninguém, os editores irão se abster de realizar comentários adicionais sobre os métodos propostos, restringindo-se a sugerir que os mesmos sejam discutidos com o médico de confiança do leitor em caso de necessidade ou dúvidas. Informações completas, atualizadas e também traduzidas para o Português estão disponíveis em <https://covid19criticalcare.com/covid-19-protocols/translations/>. Somos gratos ao Dr. Marik pela gentileza de nos ceder seu tempo neste período conturbado.

Palavras-chave: covid-19, saúde publica, tratamento medico.

\section{EDITORIAL}

This brief note introduces the reproduction of medical content, authored by Doctor Paul E. Marik. Dr. Marik is Professor of Medicine and Chief of Pulmonary Medicine and Critical Care at Eastern Virginia Medical School in Norfolk, Virginia (USA). Dr. Marik is an extremely qualified and experienced professional. The reprinting of the material was authorized by Dr. Marik himself on 12/02/2020. This material is relevant in the Brazilian scenario due to standardized procedures for patients infected with the coronavirus. Only 1 of the 5 files kindly provided by the author, in PDF format, was selected and reproduced as received, without any editing. Due to the pandemic's long duration, the Journal editors (who are not medical doctors) have already had the opportunity to monitor the development of the disease in more than one infected person. The type of treatment offered to patients seems to influence the course, duration, and severity of the disease. The treatments described in the materials below appear to be effective and have good results. The editors will refrain from making additional comments on the proposed methods not to influence anyone, restricting themselves to suggesting that they be discussed with the reader's trusted doctor in case of need or doubts. Complete, updated information and also translated into Portuguese are available at <https://covid19criticalcare.com/covid-19-protocols/translations/>. We are grateful to Dr. Marik for his kindness in giving us his time in this troubled period.

Keywords: covid-19, public health, medical treatment. 


\section{Reprodução de conteudo}

An overview of the MATH+ and I-MASK+ Protocols 


\section{An overview of the MATH+ and I-MASK+ Protocols A Guide to the Management of COVID-19}

Developed and Updated by Paul Marik, MD, FCP (SA), FRCP (C), FCCP, FCCM for the COVID-19 Critical Care Alliance (FLCCC Alliance).

This is our recommended approach to COVID-19 based on the best (and most recent) literature. This is a highly dynamic topic; therefore, we will be updating the guideline as new information emerges. Please check on the FLCCC Alliance website for updated versions of this protocol. www.flccc.net

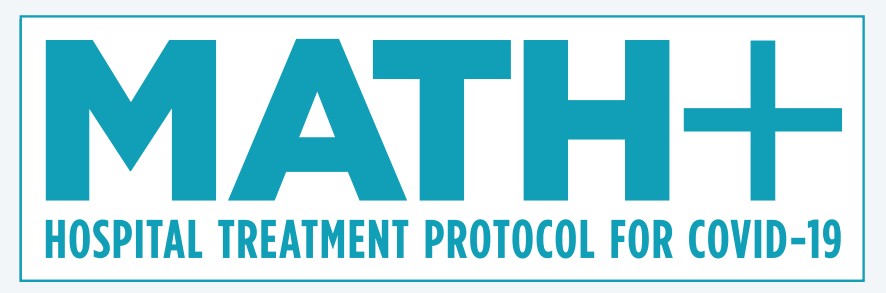

Intravenous Methylprednisolone

High Dose Intravenous Ascorbic Acid (Vitamin C)

Thiamine (Vitamin B1)

\section{Low Molecular Weight Heparin}

4

Statin - Zinc - Vitamin D - Famotidine - Melatonin - Magnesium

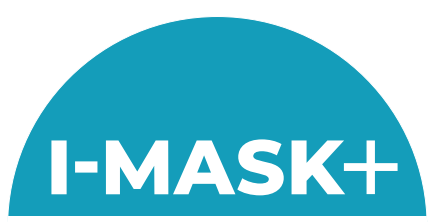

\section{MATH+}

Disclaimer: The information in this document is provided as guidance to physicians World-Wide on the prevention and treatment of COVID-19. Our guidance should only be used by medical professionals in formulating their approach to COVID-19. Patients should always consult with their physician before starting any medical treatment.

The FLCCC Alliance ${ }^{\mathrm{TM}}$ is registered as a 501(c)(3) non-profit organization. 
Figure 1. The course of COVID-19 and General Approach to treatment

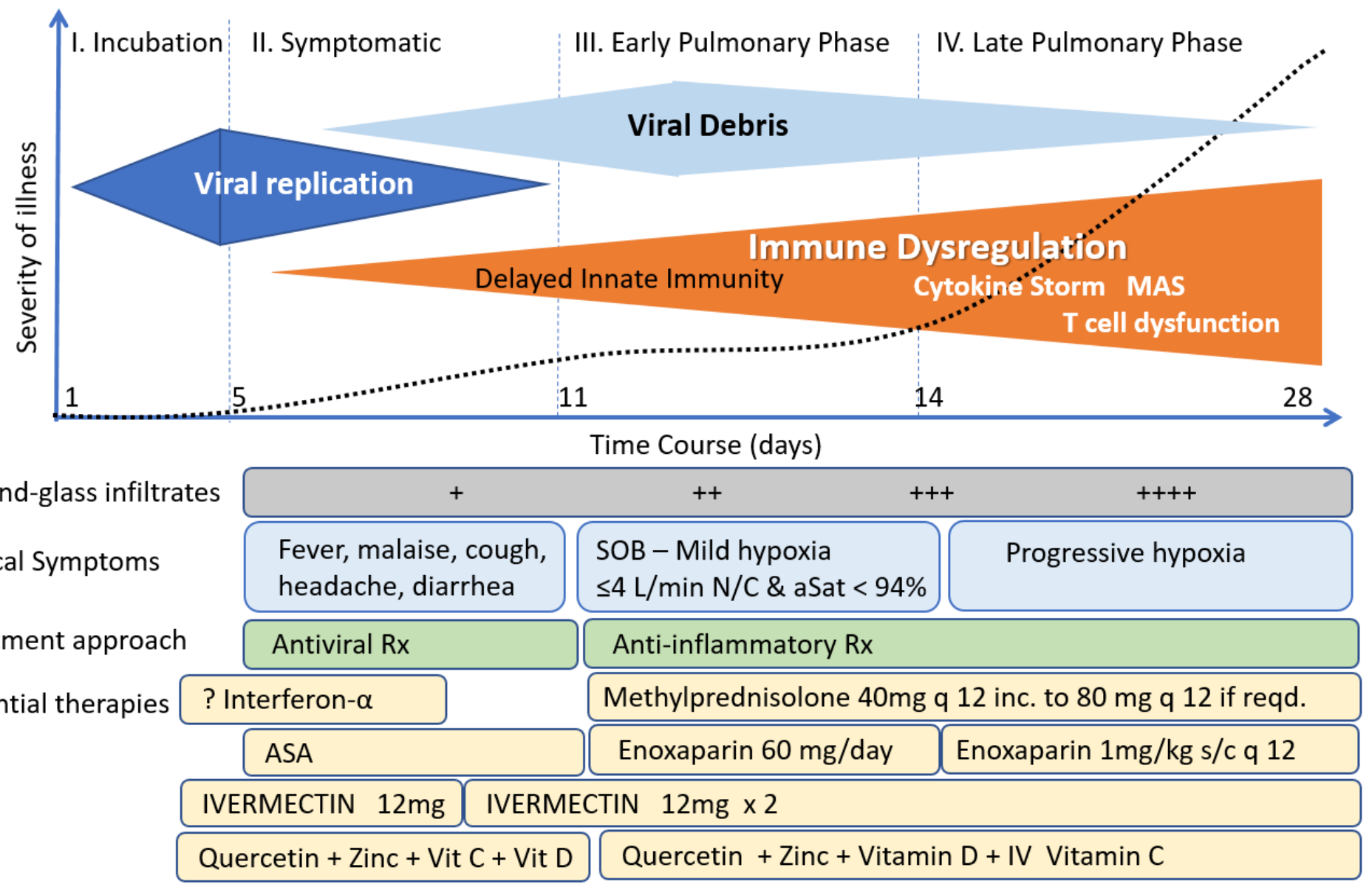

\title{
THIS IS A STEROID RESPONSIVE DISEASE:
}

\author{
HOWEVER, TIMING IS CRITICAL
}


Table 1. Pharmacological therapy for COVID by stage of illness: What has worked and what has failed*

\begin{tabular}{|l|c|c|l|}
\hline & $\begin{array}{l}\text { Pre-exposure/ } \\
\text { Post-Exposure/ } \\
\text { Incubation }\end{array}$ & Symptomatic Phase & $\begin{array}{l}\text { Pulmonary/ } \\
\text { inflammatory } \\
\text { phase }\end{array}$ \\
\hline Hydroxychloroquine & $\begin{array}{c}\text { Unclear benefit } \\
\text { nemdesivir }\end{array}$ & No benefit & ? Trend to harm \\
\hline Lopivinar-Ritonavir & n/a & $\begin{array}{c}\text { ?? Reduced time to recovery } \\
\text { No mortality benefit }\end{array}$ & No benefit \\
\hline Interferon $\alpha / \beta$ & Inhaled ? Benefit & No benefit & No benefit \\
\hline Tocilizumab & n/a benefit & ?Trend harm \\
\hline Convalescent Serum & n/a & n/a & No Benefit \\
\hline Corticosteroids & n/a & Trend to harm & No Benefit \\
\hline Ivermectin & BENEFIT & BENEFIT & BENEFIT \\
\hline
\end{tabular}

*based on randomized controlled trials (see supporting information below) 
Figure 2. Timing of the initiation of anti-inflammatory therapy
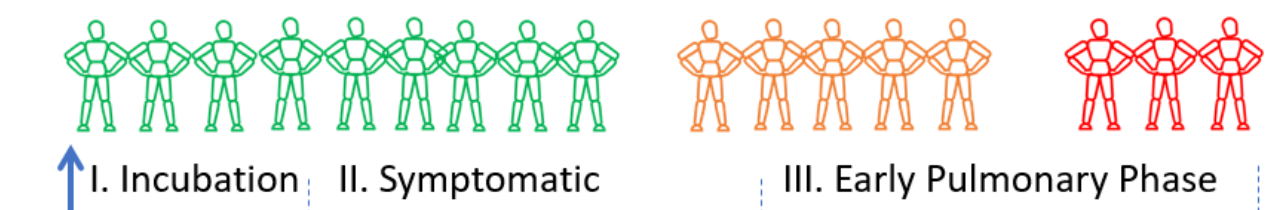

III. Early Pulmonary Phase

IV. Late Pulmonary Phase

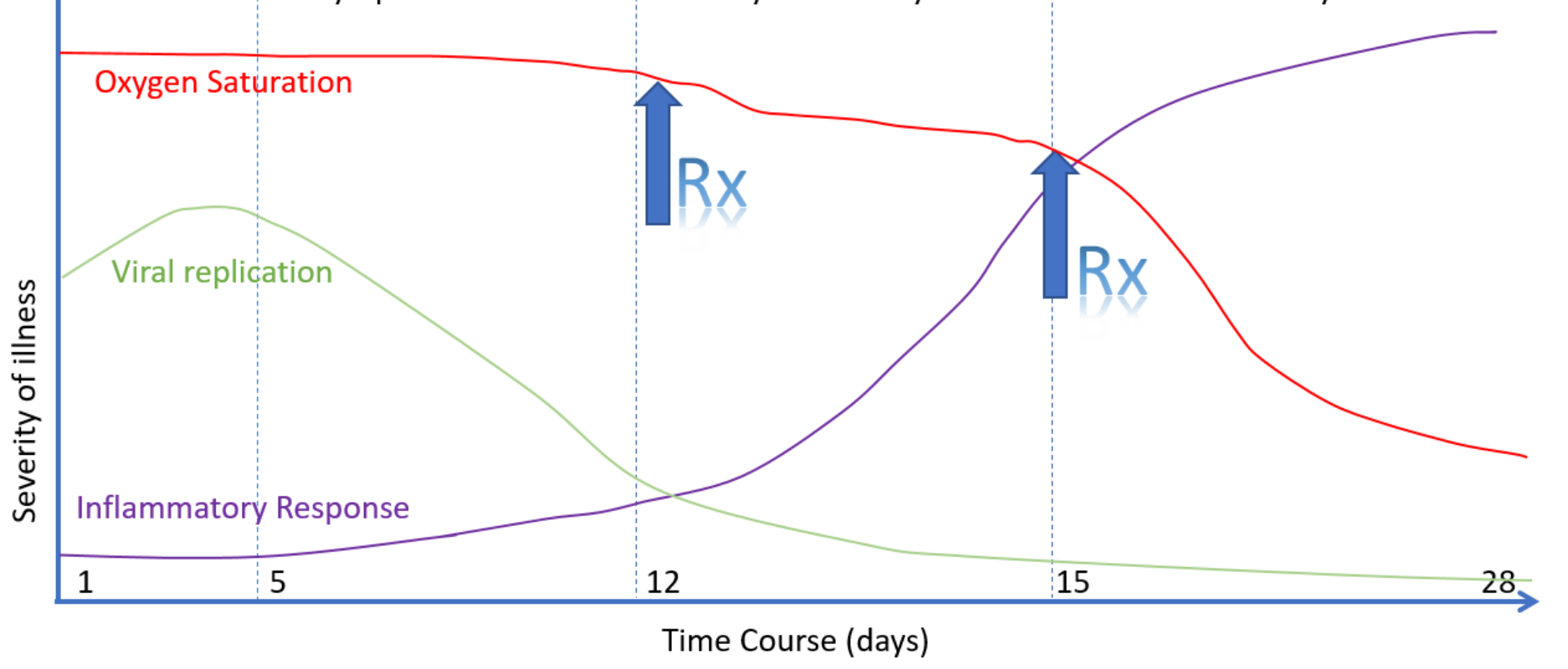

Antiviral Rx

Start Anti-inflammatory Rx

Escalate Anti-inflammatory Rx 
Figure 3. Time course of laboratory tests for COVID-19
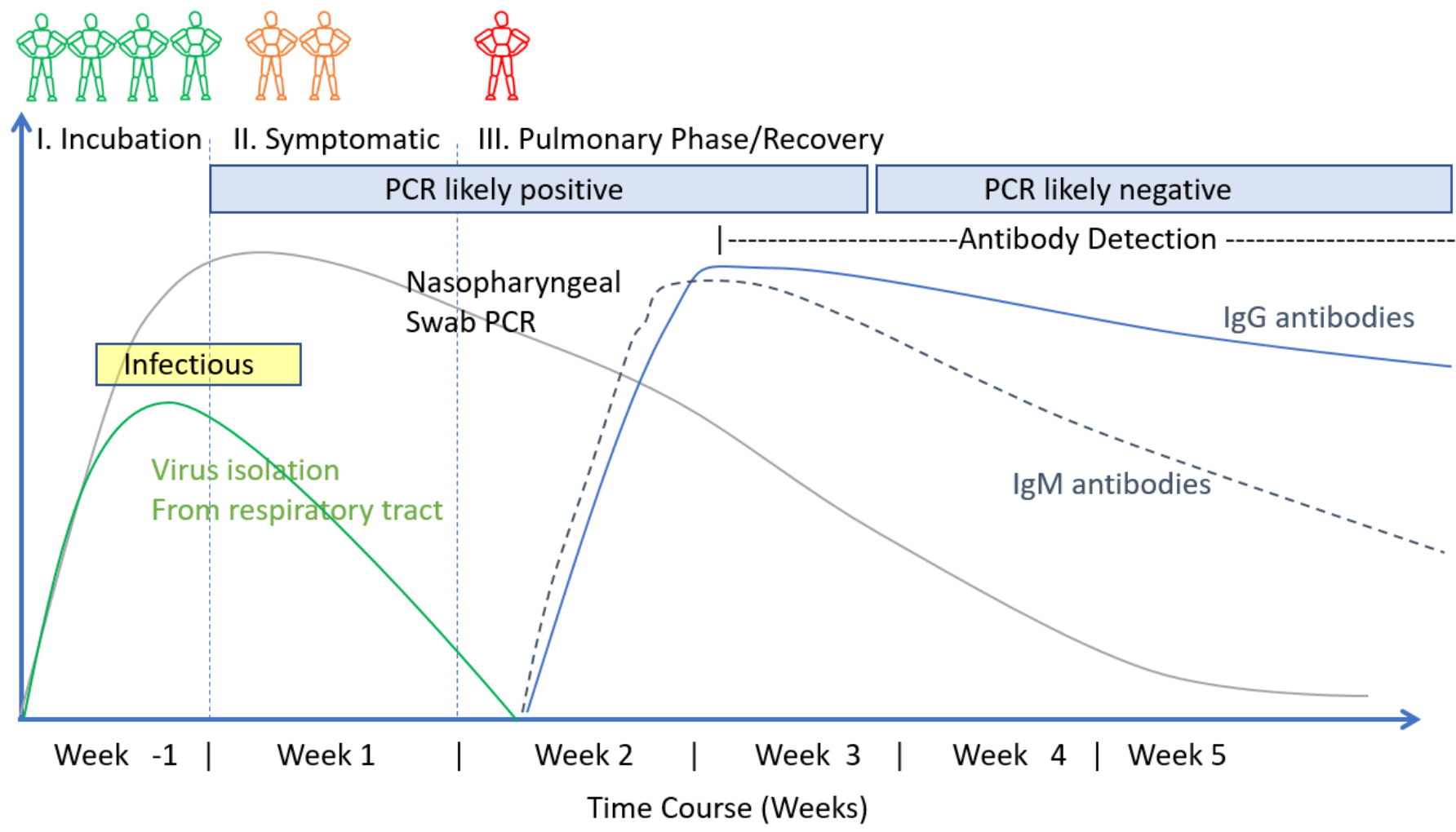

Figure 4. SARS-Co-V-2 RNA genome

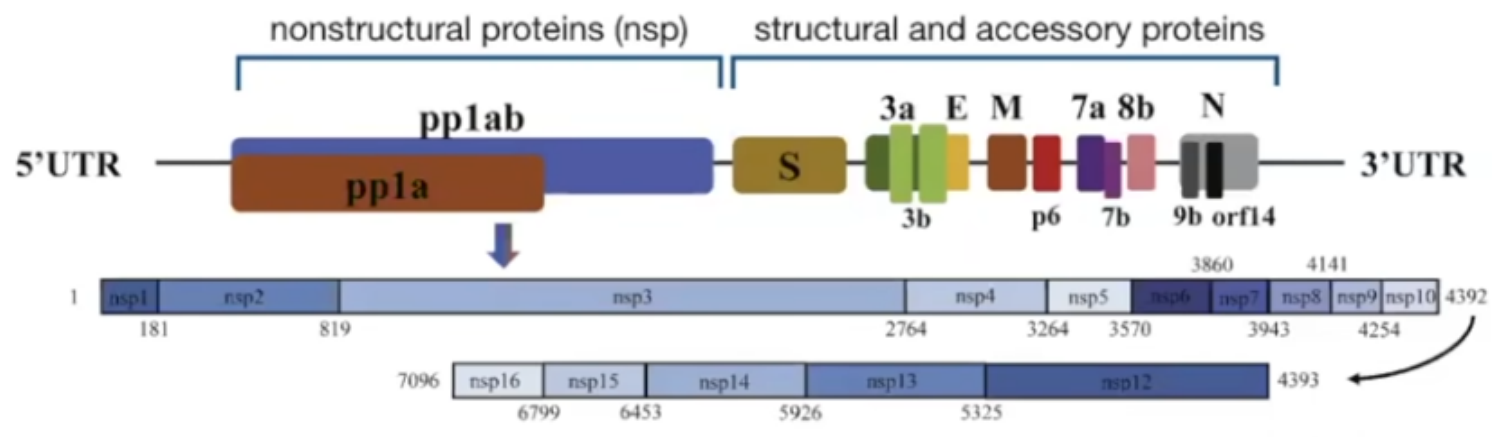

IVDC-HB-01/2019 ( 29.8kb) 
It should be noted that there is no cure or "Magic-bullet" for the prevention or treatment of COVID-19. However, recently, a number of therapeutic agents have shown promise for both the prevention and treatment of COVID-19 including ivermectin, Vitamin D, quercetin, melatonin and corticosteroids. Furthermore, it is likely that no single drug will be effective in treating this complex disease and that multiple drugs with different mechanisms of action and used in specific phases of the disease will be required.

\section{Prophylaxis}

While there is no "Level 1 evidence" that this "cocktail" will prevent/mitigate against COVID-19 we believe there is significant evidence supporting the efficacy of the individual agents included in the prophylactic protocol. This protocol MUST be part of an overall strategy which includes common sense public health measures, i.e. masks, social distancing, and avoidance of large groups of people.

Furthermore, it should be noted that there is emerging evidence suggesting that IVERMECTIN may be highly effective in the prevention and treatment of COVID-19. It is important to emphasize that ALL of the medications included in our prophylactic regimen are inexpensive, safe, and widely available.

- Vitamin D3 1000-3000 IU/day. Note RDA (Recommended Daily Allowance) is 800-1000 IU/day. The safe upper-dose daily limit is likely < 4000 IU/day. [1-22] Vitamin D insufficiency has been associated with an increased risk of acquiring COVID-19 and from dying from the disease. Vitamin D supplementation may therefore prove to be an effective and cheap intervention to lessen the impact of this disease, particularly in vulnerable populations, i.e. the elderly, those of color, obese and those living $>45^{\circ}$ latitude. [7-22]

- Vitamin C $500 \mathrm{mg}$ BID (twice daily) and Quercetin $250 \mathrm{mg}$ daily. [23-34] It is likely that vitamin C and quercetin have synergistic prophylactic benefit. [35] It should be noted that in vitro studies have demonstrated that quercetin and other flavonoids interfere with thyroid hormone synthesis at multiple steps in the synthetic pathway. [36-39] The use of quercetin has rarely been associated with hypothyroidism. The clinical impact of this association may be limited to those individuals with pre-existent thyroid disease or those with sub-clinical thyroidism. [40] In women high consumption of soya was associated with elevated TSH concentrations. [41] The effect on thyroid function may be dose dependent, hence for chronic prophylactic use we suggest that the lowest dose be taken. Quercetin should be used with caution in patients with hypothyroidism and TSH levels should be monitored. It should also be noted quercetin may have important drug-drug interactions; the most important drug-drug interaction is with cyclosporin and tacrolimus. [42] In patients taking these drugs it is best to avoid quercetin; if quercetin is taken cyclosporin and tacrolimus levels must be closely monitored.

- Melatonin (slow release): Begin with $0.3 \mathrm{mg}$ and increase as tolerated to $2 \mathrm{mg}$ at night. [43-50]

- Zinc 30-50 mg/day (elemental zinc). [23,30,32,33,51-55]

- B complex vitamins [56-60]

- Ivermectin for postexposure prophylaxis (see ClinTrials.gov NCT04422561). $0.2 \mathrm{mg} / \mathrm{kg}$ (12 mg) immediately then repeat day 3.

- Ivermectin for pre-exposure prophylaxis (in HCW) and for prophylaxis in high risk individuals (> 60 years with co-morbidities, morbid obesity, long term care facilities, etc). $0.15-0.2 \mathrm{mg} / \mathrm{kg}$ (or $12 \mathrm{mg}$ ) Day 1, Day 3 and then every 4 weeks. [5,61,62] (also see ClinTrials.gov NCT04425850). NB. Ivermectin has a number of potentially serious drug-drug interactions. Please check for potential drug interaction at Ivermectin Drug Interactions - Drugs.com. The most important drug interactions occur with cyclosporin, tacrolimus, anti-retroviral drugs and certain anti-fungal drugs. 
- Optional: Famotidine 20-40 mg/day [55-61]. Low level evidence suggests that famotidine may reduce disease severity and mortality. However, the findings of some studies are contradictory. While it was postulated that famotidine inhibits the SARSCoV-2 papain-like protease (PLpro) as well as the main protease (3CLpro) this mechanism has been disputed.[58] Furthermore, a single study suggested that users of PPI's had a significantly increased odds for reporting a positive COVID-19 test when compared with those not taking PPIs, while individuals taking histamine-2 receptor antagonists were not at elevated risk. [62] This data suggest that famotidine may be the drug of choice when acid suppressive therapy is required.

- Optional/Experimental: Interferon- $\alpha$ nasal spray for health care workers [54]

\section{Symptomatic patients at home (for the duration of acute symptoms)}

- Vitamin C $500 \mathrm{mg}$ BID and Quercetin 250-500 mg BID

- Zinc 75-100 mg/day (elemental zinc)

- Melatonin $10 \mathrm{mg}$ at night (the optimal dose is unknown) [50]

- Vitamin D3 2000-4000 IU/day. Calcifediol $0.2 \mathrm{mg}$ is an alternative. [63]

- Highly recommended: Ivermectin $0.15-0.2 \mathrm{mg} / \mathrm{kg}$ orally (repeat on day 3). [1-5,62,64-74] See Table 1, Figure 5 and ClinTrials.gov NCT04523831. See drug-drug interactions above.

- ASA 81-325 mg/day (unless contraindicated). ASA has antiinflammatory, antithrombotic, and antiviral effects. $[75,76]$ Platelet activation may play a major role in propagating the prothrombotic state associated with COVID-19. [77]

- B complex vitamins

- Optional: Famotidine $40 \mathrm{mg}$ BID (reduce dose in patients with renal dysfunction) [78-84].

- Optional: Vascepa (Ethyl eicosapentaenoic acid) 4g daily or Lovaza (EPA/DHA) 4g daily; alternative DHA/EPA 4g daily. Vascepa and Lovaza tablets must be swallowed and cannot be crushed, dissolved or chewed. Omega-3 fatty acids have anti-inflammatory properties and play an important role in the resolution of inflammation. In addition, omega-3 fatty acids may have antiviral properties. [32,85-88]

- Optional: Interferon- $\alpha / \beta \mathrm{s} / \mathrm{c}$, nasal spray or inhalation. [89-92] It should be noted that Zinc potentiates the effects of interferon.[93,94]

- In symptomatic patients, monitoring with home pulse oximetry is recommended (due to asymptomatic hypoxia). The limitations of home pulse oximeters should be recognized, and validated devices are preferred.[95] Multiple readings should be taken over the course of the day, and a downward trend should be regarded as ominous.[95] Baseline or ambulatory desaturation $<94 \%$ should prompt hospital admission. [96] The following guidance is suggested: [95]

- Use the index or middle finger; avoid the toes or ear lobe

- Only accept values associated with a strong pulse signal

- Observe readings for 30-60 seconds to identify the most common value

0 Remove nail polish from the finger on which measurements are made

- Warm cold extremities prior to measurement

- Not recommended: Hydroxychloroquine (HCQ). The use of HCQ is extremely controversial.[97] The best scientific evidence to date suggests that HCQ has no proven benefit for post exposure prophylaxis, for the early symptomatic phase and in hospitalized patients. [98-115] Considering the unique pharmacokinetics of $\mathrm{HCQ}$, it is unlikely that $\mathrm{HCQ}$ would be of benefit in patients with COVID-19 infection (it takes 5-10 days to achieve adequate plasma and lung concentrations).[107,116-118] Finally, it should be recognized that those studies which are widely promoted to support the use of HCQ are severely methodologically flawed.[119-122] 
- Not recommended: Systemic or inhaled corticosteroids (budesonide). In the early symptomatic (viral replicative phase), corticosteroids may increase viral replication and disease severity.[123] An OpenSAFELY analysis in patients with COVID-19 demonstrated a higher risk of death in COPD and asthmatic patients using high dose ICS. [124] The role of ICS in the pulmonary phase is unclear as patients require systemic corticosteroids to dampen the cytokine storm, with ICS having little systemic effects.

I-MASK+

PROPHYLAXIS \& EARLY OUTPATIENT

TREATMENT PROTOCOL FOR COVID-19
Behavioral Prophylaxis

Page $1 / 2$

\section{PROPHYLAXIS PROTOCOL}

\author{
Ivermectin Prophylaxis for high risk individuals \\ $0.2 \mathrm{mg} / \mathrm{kg}^{*}$ - one dose on day 1 and day 3 , then take \\ one dose every 4 weeks
}

Post COVID-19 exposure prophylaxis**

$0.2 \mathrm{mg} / \mathrm{kg}^{*}$ - one dose on day 1 and day 3

Vitamin D3 1,000-3,000 IU/day

Vitamin C $1,000 \mathrm{mg}$ twice a day

Quercetin $250 \mathrm{mg} /$ day

Zinc $\quad 50 \mathrm{mg} /$ day

Melatonin $6 \mathrm{mg}$ before bedtime (causes drowsiness)

\section{EARLY OUTPATIENT PROTOCOL***}

Ivermectin $0.2 \mathrm{mg} / \mathrm{kg}^{*}$ - one dose on day 1 and day 3

Vitamin D3 4,000 IU/day

Vitamin C 2,000 mg 2-3 times daily

Quercetin $250 \mathrm{mg}$ twice a day

Zinc $\quad 100 \mathrm{mg} / \mathrm{day}$

Melatonin $10 \mathrm{mg}$ before bedtime

Aspirin $\quad 325 \mathrm{mg} /$ day (unless contraindicated)

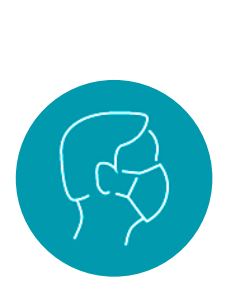

WEAR MASKS

Must wear cloth, surgical, or N95 mask (without valve) in all indoor spaces with nonhousehold persons.

Must wear a N95 mask (without valve) during prolonged exposure to nonhousehold persons in any confined, poorly ventilated area.

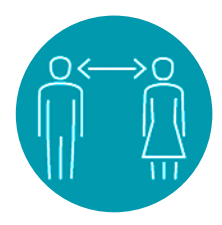

\section{KEEP DISTANCE}

Until the end of the Covid-19 crisis, we recommend keeping a minimum distance of approx. $2 \mathrm{~m} / 6$ feet in public from people who are not from your own household. 


\section{Mildly Symptomatic patients (on floor/ward in hospital):}

- Vitamin C 500-1000 mg q 6 hourly and Quercetin 250-500 mg BID (if available)

- Zinc $75-100 \mathrm{mg} /$ day

- Melatonin $10 \mathrm{mg}$ at night (the optimal dose is unknown) [50]

- Vitamin D3 20,000-60,000 IU single oral dose. Calcifediol 0.2-0.5 mg is an alternative. [63] This should be followed by 20,000 IU D3 (or $0.2 \mathrm{mg}$ calcifediol) weekly until discharged from hospital. Calcifediol is more efficiently absorbed, achieves $25-\mathrm{OH}$ vitamin $\mathrm{D}$ levels quicker and is three times more potent than vitamin D3. $[125,126]$ However, it is important to note that the optimal dose of vitamin $D$ in the acute setting is unknown. $[127,128]$ Very high doses may paradoxically block the vitamin $\mathrm{D}$ receptor.

- Highly recommended: Ivermectin $0.15-0.2 \mathrm{mg} / \mathrm{kg}$ orally $(12 \mathrm{mg})$ and repeat on day 3 [1$5,62,64-74]$. It should be noted that ivermectin has potent anti-inflammatory properties apart from its antiviral properties.[129-131] See Table 1 and Figure 5. See drug-drug interaction above.

- B complex vitamins

- Enoxaparin $60 \mathrm{mg} /$ day [72,132-145] Consider increasing the dose to $1 \mathrm{mg} / \mathrm{kg} \mathrm{q} 12$ hourly in those with a high D-Dimer or an increasing D-Dimer (see Xa monitoring below).

- Methylprednisolone $40 \mathrm{mg} \mathrm{q} 12$ hourly; increase to $80 \mathrm{mg}$ and then $125 \mathrm{mg} \mathrm{q} 12$ hourly in patients with progressive symptoms and increasing CRP. There is now overwhelming and irrefutable evidence that corticosteroids reduce the risk of death in patients with the pulmonary phase of COVID-19 i.e. those requiring supplemental oxygen or higher levels of support. [146158] The role of inhaled corticosteroids (budesonide) is unclear and appears to be rather limited.

- Optional: Famotidine $40 \mathrm{mg}$ BID (20-40 mg/day in renal impairment). [78-84]

- Optional: Vascepa (Ethyl eicosapentaenoic acid) 4g daily or Lovaza (EPA/DHA) 4g daily; alternative DHA/EPA 4g daily.

- Optional (not recommended): Remdesivir $200 \mathrm{mg}$ IV loading dose D1, followed by 100mg day IV for 9 days. $[159,160]$ This agent has been reported to reduce time to recovery (based on an ordinal scale) in patients requiring low levels of supplemental oxygen. $[160,161]$ The recently published SOLIDARITY trial demonstrated no mortality benefit of this agent in the entire treatment cohort or any subgroup.[162] Considering the high cost of this agent and the lack of benefit on patient centered outcomes the role of this drug seems very limited.

- $\mathrm{N} / \mathrm{C} 2 \mathrm{~L} / \mathrm{min}$ if required ( $\max 4 \mathrm{~L} / \mathrm{min}$; consider early $\mathrm{t} / \mathrm{f}$ to ICU for escalation of care).

- Avoid Nebulization and Respiratory treatments. Use "Spinhaler" or MDI and spacer if required.

- $T / f$ EARLY to the ICU for increasing respiratory signs/symptoms, increasing oxygen requirements and arterial desaturation. 
Progressive Respiratory symptoms (hypoxia- requiring N/C $\geq 4$ L min: admit to ICU):

\section{Essential Treatment (dampening the STORM); MATH + [163]}

1. Methylprednisolone $80 \mathrm{mg}$ loading dose then $40 \mathrm{mg} \mathrm{q} 12$ hourly for at least 7 days and until transferred out of ICU. In patients with an increasing CRP or worsening clinical status increase the dose to $80 \mathrm{mg} \mathrm{q} 12$ hourly (then $125 \mathrm{mg} \mathrm{q} 12$ hourly), then titrate down as appropriate. [146-158] Pulse methylprednisolone 250-500 mg mg/day may be required.[156] As depicted in Table 1, methylprednisolone is the corticosteroid of choice.

2. Ascorbic acid (Vitamin C) $3 \mathrm{~g}$ IV q 6 hourly for at least 7 days and/or until transferred out of ICU.[27,164-174]. Note caution with POC glucose testing (see below). Oral absorption is limited by saturable transport and it is difficult to achieve adequate levels with $\mathrm{PO}$ administration. However, if IV Vitamin C is not available, attempts should be made to administer PO vitamin C at a dose of $1 \mathrm{~g}$ every $4-6$ hours.

3. Full anticoagulation: Unless contraindicated we suggest FULL anticoagulation (on admission to the ICU) with enoxaparin, i.e. $1 \mathrm{mg} \mathrm{kg} \mathrm{s} / \mathrm{c} \mathrm{q} 12$ hourly (dose adjust with $\mathrm{Cr} \mathrm{Cl}<30 \mathrm{mls} / \mathrm{min}$ ). There is now good evidence that high intensity anticoagulation reduces mortality of hospitalized patients with COVID-19. [132,134,135,137-145,175] Heparin is suggested with $\mathrm{CrCl}<15 \mathrm{ml} / \mathrm{min}$. Due to augmented renal clearance patients may have reduced anti-Xa activity despite standard dosages of LMWH.[176] We therefore recommend monitoring anti-Xa activity in underweight and obese patients, those with chronic renal failure and in those patients with an increasing D-dimer, aiming for an anti-Xa activity of 0.6-1.1 IU.ml.

Note: A falling $\mathrm{SaO} 2$ and the requirement for supplemental oxygen should be a trigger to start antiinflammatory treatment (see Figure 2).

Note: Early termination of ascorbic acid and corticosteroids will likely result in a rebound effect with clinical deterioration (see Figure 6).

\section{Additional Treatment Components (the Full Monty)}

4. Highly recommended: Ivermectin $0.15-0.2 \mathrm{mg} / \mathrm{kg}$ orally (repeat on day 2). Alternative strategy is a dose of $12 \mathrm{mg}$ within 24 hours of symptom onset and then repeated 24 hours later. [1-5,62,6474]. [1-3,64,67-74,129-131,177-184] Note that ivermectin has potent antiviral and antinflammatory effects.[129-131] See Table 1 and Figure 5.

5. Melatonin $10 \mathrm{mg}$ at night (the optimal dose is unknown).

6. Vitamin D3 20,000-60,000 IU single oral dose. Calcifediol $0.2-0.5 \mathrm{mg}$ is an alternative. This should be followed by 20,000 IU D3 (or $0.2 \mathrm{mg}$ calcifediol) weekly until discharged from hospital.

7. Thiamine $200 \mathrm{mg}$ IV q 12 hourly [185-190] Thiamine may play a role in dampening the cytokine storm. [186]

8. B complex vitamins

9. Magnesium: $2 \mathrm{~g}$ stat IV. Keep Mg between 2.0 and $2.4 \mathrm{mmol} / \mathrm{l}$. [59] Prevent hypomagnesemia (which increases the cytokine storm and prolongs Qtc). [191-193]

10. Optional: Doxycycline $100 \mathrm{mg}$ daily for 5 days doxycycline is a broad spectrum antibiotics which appears to have synergistic anti-viral and anti-inflammatory effects when combined with Ivermectin.

11. Optional (Consider in severe cases). Anti-serotonin agents. It appears that excess release of serotonin from platelets may contribute to the "cytokine storm". Therefore, the "serotonin receptor blocker" cyproheptadine 4-8 mg PO q 6 hours should be considered. This may explain the beneficial effects of serotonin re-uptake inhibitors in patients with COVID-19. $[194,195]$ 
12. Optional (Consider in severe cases). ASA $325 \mathrm{mg}$ daily. As note above platelet activation and the release of serotonin may play a role in the pathophysiology of severe COVID-19. As the risk of significant bleeding in increased in patients receiving both ASA and heparin, ASA should not be used in patients at high risk of bleeding. In addition (as noted below) patients should receive famotine concurrently.

13. Optional. Atorvastatin $80 \mathrm{mg} /$ day. Statins have pleotropic anti-inflammatory, immunomodulatory, antibacterial, and antiviral effects. In addition, statins decrease expression of PAI-1. Simvastatin has been demonstrated to reduce mortality in the hyper-inflammatory ARDS phenotype. [196]

Preliminary data suggests atorvastatin may improve outcome in patients with COVID-19.[197-201] Due to numerous drug-drug interactions simvastatin should be avoided.

14. Optional: Famotidine $40 \mathrm{mg}$ BID (20-40 mg/day in renal impairment). [78-84].

15. Optional: Vascepa, Lovaza or DHA/EPA 4g day (see above).

16. Not recommended: The role of azithromycin in the treatment of COVID-19 is controversial. The best information to date suggests that azithromycin is of little benefit.[202,203]

17. Not recommended: Remdesivir. Has not benefit at this stage of the disease.

18. Not recommended. Convalescent serum $[204,205]$ or monoclonal antibodies. (Eli Lilly recently announced that they are suspending their ACTIV-33 clinical trial as their monoclonal antibody failed to demonstrate a clinical benefit in hospitalized patients).

19. Not recommended. Tocilizumab. Four RCTS have now failed to demonstrate a clinical benefit from tocilizumab. [206-209]

20. Broad-spectrum antibiotics if superadded bacterial pneumonia is suspected based on procalcitonin levels and resp. culture (no bronchoscopy). Due to the paradox of hyper-inflammation and immune suppression (a major decrease of HLA-DR on CD14 monocytes and T cell dysfunction) secondary bacterial and fungal infection is not uncommon. [210]

21. Maintain EUVOLEMIA (this is not non-cardiogenic pulmonary edema). Due to the prolonged "symptomatic phase" with flu-like symptoms (6-8 days) patients may be volume depleted. Cautious rehydration with $500 \mathrm{ml}$ boluses of Lactate Ringers may be warranted, ideally guided by noninvasive hemodynamic monitoring. Diuretics should be avoided unless the patient has obvious intravascular volume overload. Avoid hypovolemia.

22. Early norepinephrine for hypotension. It should however be appreciated that despite the cytokine storm, vasodilatory shock is distinctly uncommon in uncomplicated COVID-19 (when not complicated by bacterial sepsis). This appears to be due to the fact that TNF- $\alpha$ which is "necessary" for vasodilatory shock is only minimally elevated.

23. Escalation of respiratory support (steps); Try to avoid intubation if at all possible, (see Figure7)

- Accept "permissive hypoxemia" (keep O2 Saturation > 84\%); follow venous lactate and Central Venous $\mathrm{O}_{2}$ saturations $\left(\mathrm{ScvO}_{2}\right)$ in patents with low arterial $\mathrm{O}_{2}$ saturations

- $\mathrm{N} / \mathrm{C}$ 1-6 L/min

- High Flow Nasal canula (HFNC) up to $60-80 \mathrm{~L} / \mathrm{min}$

- Trial of inhaled Flolan (epoprostenol)

- Attempt proning (cooperative repositioning-proning) [211,212]

- Intubation ... by Expert intubator; Rapid sequence. No Bagging; Full PPE. Crash/emergency intubations should be avoided.

- Volume protective ventilation; Lowest driving pressure and lowest PEEP as possible. Keep driving pressures $<15 \mathrm{~cm} \mathrm{H}_{2} \mathrm{O}$.

- Moderate sedation to prevent self-extubation

- Trial of inhaled Flolan (epoprostenol)

- Prone positioning. 
There is widespread concern that using HFNC could increase the risk of viral transmission. There is however, no evidence to support this fear. HFNC is a better option for the patient and the health care system than intubation and mechanical ventilation. CPAP/BiPAP may be used in select patients, notably those with COPD exacerbation or heart failure.

A sub-group of patients with COVID-19 deteriorates very rapidly. Intubation and mechanical ventilation may be required in these patients.

Table 2: Comparison of Methylprednisolone, Dexamethasone and Hydrocortisone- Number Need to Treat (NNT)

PUBLISHED RCT's/COHORT STUDIES OF CORTICOSTEROID

THERAPY IN COVID-19

\begin{tabular}{|c|c|c|}
\hline $\begin{array}{c}\text { PUBLISHED RCT's/COHORT STUDIES OF } \\
\text { CORTICOSTEROID } \\
\text { THERAPY IN COVID-19 }\end{array}$ & $\begin{array}{c}\text { ABSOLUTE } \\
\text { DIFFERENCE IN } \\
\text { MORTALITY RATE } \\
\text { (Rx Group vs. } \\
\text { Control Group) }\end{array}$ & $\begin{array}{c}\text { ESTIMATED } \\
\text { NUMBER } \\
\text { NEEDEDTO } \\
\text { TREATTO } \\
\text { SAVE ONE } \\
\text { LIFE }\end{array}$ \\
\hline METHYLPREDNISONE - HOSPITAL PATIENTS (Edalatifard et al, Iran) & $5.9 \%$ vs. $42.9 \%$ & 2.7 \\
\hline METHYLPREDNISONE - ICU PATIENTS (Salton et al, Italy) & $7.2 \%$ vs. $23.3 \%$ & 6.2 \\
\hline METHLPREDNISONE - HOSPITAL PATIENTS, (Fadel et al, USA) & $13.6 \%$ vs. $26.3 \%$ & 7.8 \\
\hline METHYLPREDNISONE- ARDS PATIENTS (Wu C et al- China) & $46.0 \%$ vs. $61.8 \%$ & 6.3 \\
\hline METHYLPREDNISONE - Pts on oxygen - (Fernandez-Cruz, Spain) & $13.9 \%$ vs. $23.9 \%$ & 10.0 \\
\hline CoDEX -DEXAMETHASONE - MECHANICAL VENTILATION & $56.3 \%$ vs $61.5 \%$ & 19.2 \\
\hline \multirow{2}{*}{ RECOVERY TRIAL (DEXAMATHASONE) } & $23.3 \%$ vs. $26.2 \%$ & 28.6 \\
\hline & $29.3 \%$ vs. $41.4 \%$ & 8.4 \\
\hline HYDROCORTISONE -CAPE-COVID - ICU Patients (Dequin et al France) & $14.7 \%$ vs $27.4 \%$ & 7.9 \\
\hline HYDROCORTISONE -REMAP-CAP - ICU patients & $28 \% \%$ vs $33 \%$ & 20.0 \\
\hline
\end{tabular}


Figure 5. Metaanalysis of Ivermectin clinical studies (in hospital mortality)

\begin{tabular}{|c|c|c|c|c|c|c|c|c|c|c|}
\hline \multirow{2}{*}{$\frac{\text { Group by }}{\text { RCT-Obs }}$} & \multirow[t]{2}{*}{$\underline{\text { Study name }}$} & \multicolumn{5}{|c|}{$\underline{\text { Statistics for each study }}$} & \multicolumn{4}{|c|}{ Odds ratio and $95 \% \mathrm{Cl}$} \\
\hline & & $\begin{array}{l}\text { Odds } \\
\text { ratio }\end{array}$ & $\begin{array}{c}\text { Lower } \\
\text { limit }\end{array}$ & $\begin{array}{l}\text { Upper } \\
\text { limit }\end{array}$ & Z-Value & p-Value & & & & \\
\hline OBS & Rajter & 0.524 & 0.287 & 0.958 & -2.099 & 0.036 & & & & \\
\hline OBS & Khan & 0.121 & 0.015 & 0.969 & -1.990 & 0.047 & & & & \\
\hline OBS & Gorial & 0.842 & 0.039 & 18.393 & -0.109 & 0.913 & & & & \\
\hline OBS & & 0.477 & 0.270 & 0.844 & -2.546 & 0.011 & & & & \\
\hline $\mathrm{RCT}$ & Mahmud & 0.138 & 0.007 & 2.694 & -1.306 & 0.192 & & & & \\
\hline RCT & Hashim & 0.314 & 0.061 & 1.611 & -1.389 & 0.165 & & & & \\
\hline RCT & Elgazzar & 0.074 & 0.017 & 0.318 & -3.502 & 0.000 & & & & \\
\hline RCT & Niaee & 0.154 & 0.047 & 0.506 & -3.080 & 0.002 & & & & \\
\hline RCT & & 0.146 & 0.067 & 0.316 & -4.868 & 0.000 & & & & \\
\hline \multirow[t]{3}{*}{ Overall } & & 0.315 & 0.199 & 0.498 & -4.933 & 0.000 & & & & \\
\hline & & & & & & & 0.01 & 0.1 & 10 & 100 \\
\hline & \multicolumn{10}{|c|}{ Favours Ivermectin } \\
\hline
\end{tabular}

Meta Analysis

\section{Salvage Treatments}

- High dose bolus corticosteroids; $250-500 \mathrm{mg} /$ day methylprednisolone $[154,156]$ Plasma exchange [213-219]. Should be considered in patients with progressive oxygenation failure despite corticosteroid therapy as well as in patients with severe MAS. Patients may require up to 5 exchanges. FFP is required for the exchange; giving back "good humors" appears to be more important than taking out "bad humors".

- In patients with a large dead-space ventilation i.e. high $\mathrm{PaCO}_{2}$ despite adequate minute ventilation consider "Half-dose rTPA" to improve pulmonary microvascular blood flow; $25 \mathrm{mg}$ of tPA over 2 hours followed by a 25mg tPA infusion administered over the subsequent 22 hours, with a dose not to exceed $0.9 \mathrm{mg} / \mathrm{kg}$ followed by full anticoagulation.[220,221]

- ECMO [222,223]. Unlike "typical ARDS" COVID-19 patients do not progress into a resolution phase. Rather, patients with COVID-19 may progress to a severe fibro-proliferative phase and ventilator dependency. ECMO in these patients would likely serve little purpose. ECMO however may improve survival in patients with severe single organ failure (lung) if initiated within 7 days of intubation. [224]

- Combination inhaled nitric oxide (or epoprostenol) and intravenous almitrine. The combination of inhaled nitric oxide, a selective pulmonary vasodilator, and almitrine, a specific pulmonary vasoconstrictor, may improve the severe $\mathrm{V} / \mathrm{Q}$ mismatch in patients with severe COVID-19 “pneumonia”. [225-228] 
Figure 6. Premature discontinuation of corticosteroids and IV vitamin C (after 4 day) and the effect of reinitiation of this combination on the CRP profile.

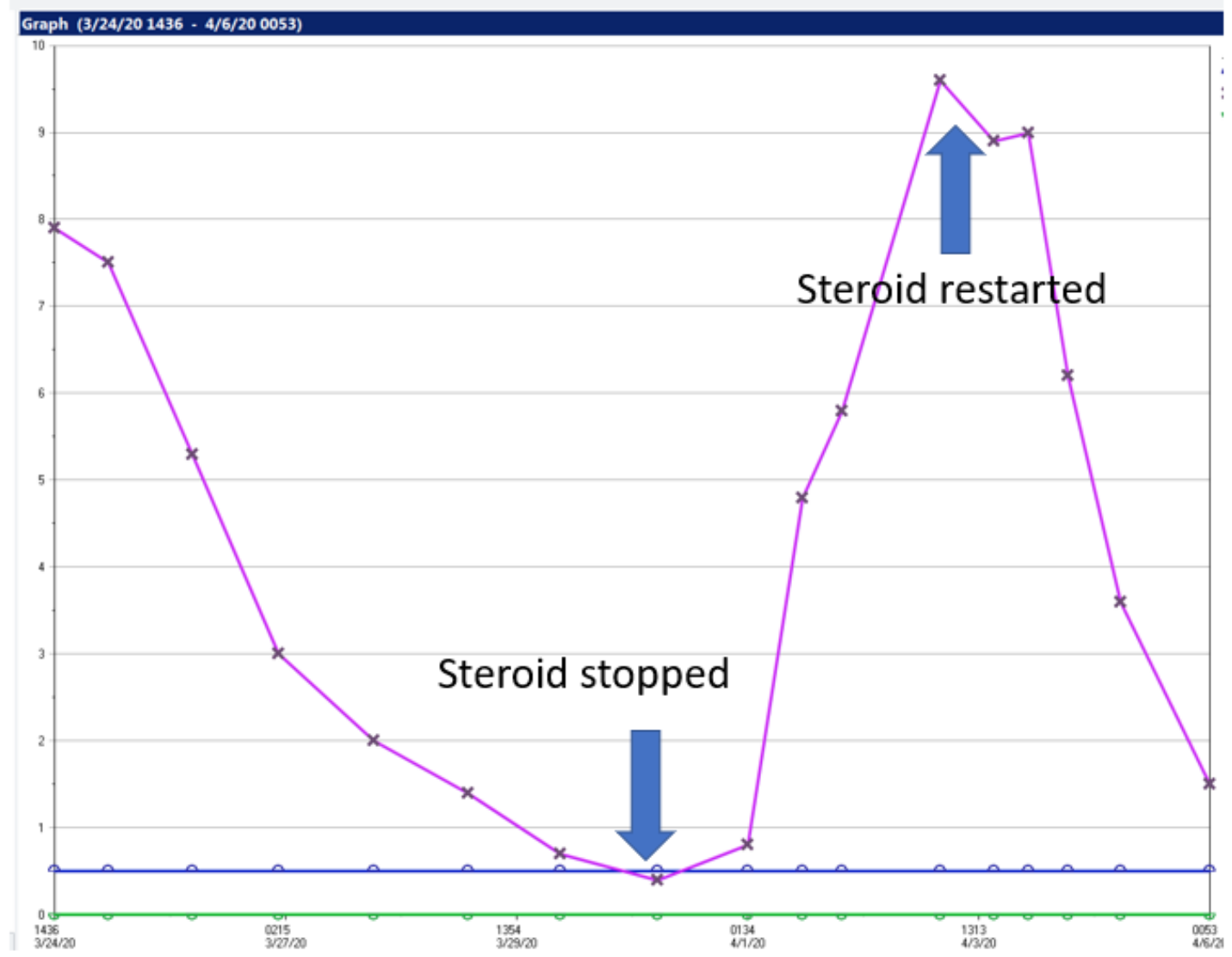

Salvage treatments of unproven/no benefit.

- Convalescent serum/monoclonal antibodies: the role and timing of convalescent serum and monoclonal antibodies are uncertain. [229-232] Two RCT's failed to demonstrate any clinical benefit with convalescent serum. [204,205] In addition, Eli Lilly recently announced that they are suspending their ACTIV-33 clinical trial as their monoclonal antibody failed to demonstrate a clinical benefit in hospitalized patients. It is noteworthy that the only RCT demonstrating efficacy of convalescent plasma for an infectious disease was conducted more than 40 years ago, for treating Argentine hemorrhagic fever. [211] Furthermore, giving antibodies directed against SARS-CoV-2 appears pointless when the virus is already DEAD (pulmonary phase). In addition, IgG is a large protein which penetrates tissues poorly, and is unlikely to achieve submucosal concentrations required for mucosal immunity.[233] And lastly, COVID-19 pulmonary disease is immune mediated, and it would therefore appear paradoxical to enhance the antibody response with convalescent serum. [234]

- Janus Kinase inhibitors downregulate cytokine expression and may have a role in this disease. [235-237] 
- In patients with progressive fibrosis the combination of anti-fibrotic therapy with corticosteroids should be considered. [238-241] It should however be recognized that unlike all the medications in the MATH+ protocol, pirfenidone and nintedanib have complex sideeffects and drug interactions and should be prescribed by pulmonary physicians who have experience with these drugs.

- $\mathrm{CVVH} / \mathrm{D}$ with cytokine absorbing/filtering filters $[242,243]$ This treatment strategy appears to have a very limited role.

\section{Treatment of Macrophage Activation Syndrome (MAS)}

- A sub-group of patients will develop MAS, particularly those patients with severe COVID-19 disease.[244] While the pathophysiology of MAS in the setting of COVID-19 is unclear this appears to be driven by SARS-CoV-2 induced inflammasome activation and increased IL-18 production as well as increased GM-CSF and INFy production. [245-248] The role of IL-1 and $\mathrm{IL}-6$ in the pathogenesis of MAS is unclear.

- A ferritin $>4400 \mathrm{ng} / \mathrm{ml}$ is considered diagnostic of MAS. Other diagnostic features include increasing AST/ALT and CRP and progressive multi-system organ failure.[249]

- "High dose corticosteroids." Methylprednisolone $120 \mathrm{mg}$ q 6-8 hourly for at least 3 days, then wean according to Ferritin, CRP, AST/ALT (see Figure 8). Ferritin should decrease by at least $15 \%$ before weaning corticosteroids.

- Consider plasma exchange.

- The role of inhibition of IL-1 (Anakinra) and IFNy (emapalumab) is unclear (NCT04324021).

\section{Monitoring}

- On admission: Procalcitonin (PCT), CRP, BNP, Troponins, Ferritin, Neutrophil-Lymphocyte ratio, D-dimer and Mg. CRP and D-dimer are important prognostic markers. A PCT is essential to rule out coexisting bacterial pneumonia.

- Daily: CRP, Ferritin, D-Dimer and PCT. CRP and Ferritin track disease severity closely (although ferritin tends to lag behind CRP). Early high CRP levels are closely associated with the degree of pulmonary involvement and the CT score. [250]

- In patients receiving IV vitamin C, the Accu-Chek ${ }^{\mathrm{TM}}$ POC glucose monitor will result in spuriously high blood glucose values. Therefore, a laboratory glucose is recommended to confirm the blood glucose levels. [251,252]

- No routine CT scans, follow CXR and chest ultrasound.

- ECHO as clinically indicated; Pts may develop a severe "septic" cardiomyopathy. 
Figure 7.

General schema for respiratory support in patients with COVID-19 Try to avoid intubation if possible

\section{Low flow nasal cannula}

- Typically set at 1-6 liters/minute

\section{High flow nasal cannula}

- Accept permissive hypoxemia $\left(\mathrm{O}_{2}\right.$ Saturation $\left.>86 \%\right)$

- Titrate $\mathrm{FiO}_{2}$ based on patient's saturation

- Accept flow rates of 60 to $80 \mathrm{~L} / \mathrm{min}$

- Trial of inhaled Flolan (epoprostenol)

- Attempt proning (cooperative proning)

\section{Invasive mechanical ventilation}

- Target tidal volumes of $\sim 6 \mathrm{cc} / \mathrm{kg}$.

- Lowest driving pressure and PEEP

- Sedation to avoid self-extubation

- Trial of inhaled Flolan

\section{Prone positioning}

- Exact indication for prone ventilation is unclear.

- Consider in patients with $\mathrm{PaO}_{2} / \mathrm{FiO}_{2}$ ratio $<150$.

\section{Salvage Therapies}

- High dose corticosteroids; 120-250 mg methylprednisolone q6-8

- Plasma exchange

- "Half-dose" rTPA 
Figure 8. SARS-CoV-2 induced Macrophage Activation Syndrome (MAS) treated with Vitamin C $3 g$ IV q 6 and increased methylprednisolone (125 mg q 8 hourly)

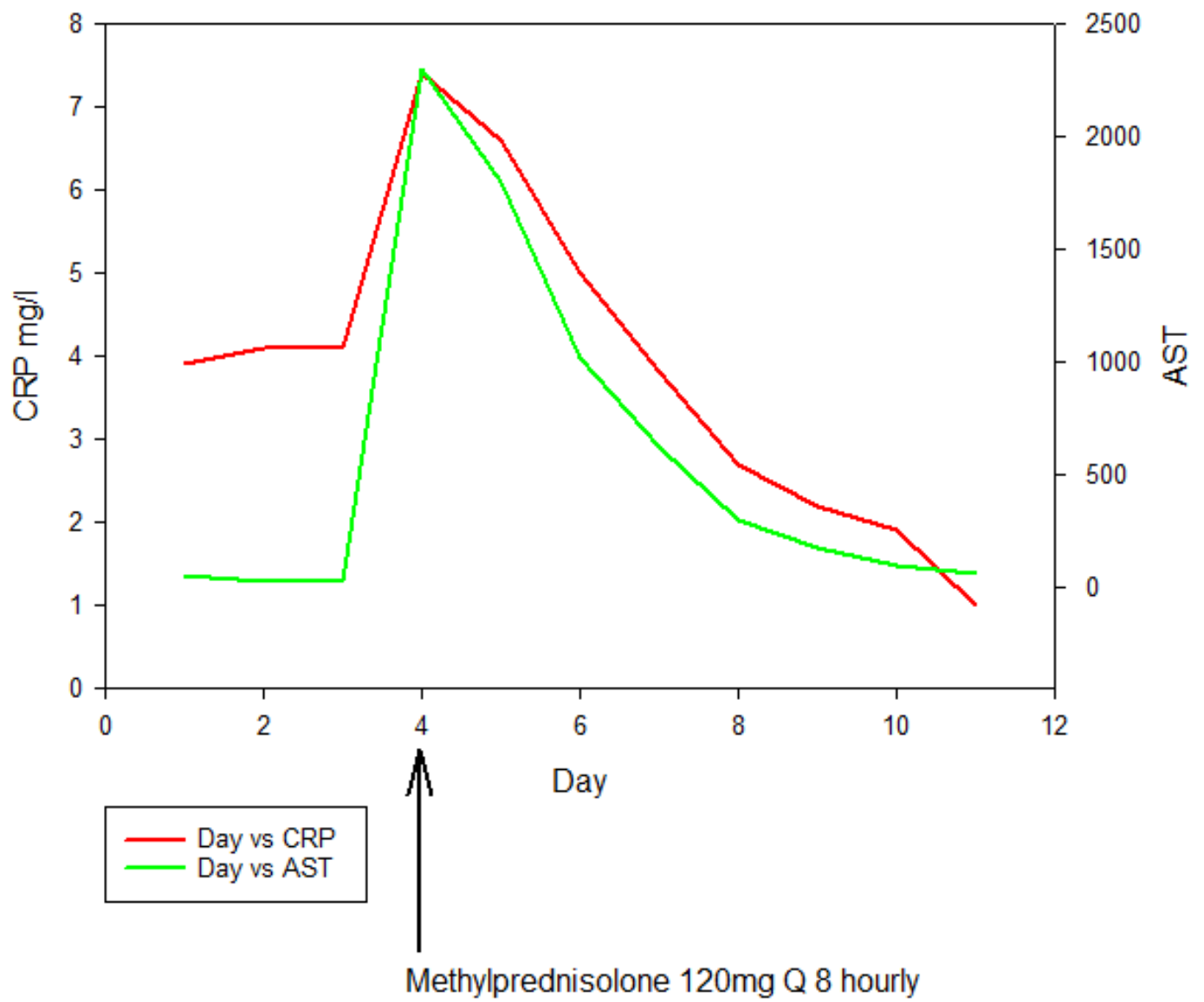




\section{Post ICU management}

a. Enoxaparin 40-60 mg s/c daily

b. Methylprednisolone $40 \mathrm{mg}$ day, then wean slowly (follow CRP)

c. Vitamin C $500 \mathrm{mg}$ PO BID

d. Melatonin 3-6 mg at night

e. Vascepa, Lovaza or DHA/EPA 4g day (important for resolution of inflammation)

\section{Post Hospital Discharge management}

a. Patients have an increased risk of thromboembolic events post-discharge. [253] Extended thromboprophylaxis (? with a DOAC) should be considered in high risk patients. Risk factors include:[254]

i. Increased D dimer ( $>2$ times ULN)

ii. Increased CRP ( $>2$ times ULN) [255]

iii. Age $>60$

iv. Prolonged immobilization

b. The post-COVID-19 syndrome, is characterized by prolonged malaise, headaches, generalized fatigue, painful joints, dyspnea, chest pain and cognitive dysfunction.[256-258] Up to 50\% of patients experience prolonged illness after Covid-19. The post-COVID-19 syndrome may persistent for months after the acute infection and almost half of patients report reduced quality of life. The neurological symptoms may be related micro- and/or macrovascular thrombotic disease which appears to be common in severe COVID-19 disease.[244] Brain MRIs' 3 months post-infection demonstrated micro-structural changes in $55 \%$ of patients. [259] Similar to patients who have recovered from septic shock, [260] a prolonged (many months) immune disturbance with elevated pro- and anti-inflammatory cytokines may contribute to the post-COVID-19 syndrome. Consequently, A CRP should be measured prior to discharge and a tapering course of corticosteroids should be considered in those with an elevated CRP. It should be noted that much like omega- 3 fatty acids corticosteroids have been demonstrated to increase expression of pro-resolving lipids including Protectin D1 and Resolvin D4.[261] Other interventions that should be considered include:

i. Vascepa, Lovaza or DHA/EPA 4g day; important for resolution of inflammation by inducing resolvin production. $[87,88]$

ii. Atorvastatin $40 \mathrm{mg}$ daily (increase resolvin synthesis) [262]

iii. Continue melatonin for its antioxidant properties and stabilization of the circadian rhythms.

iv. Multivitamin with adequate vitamin D.

v. Recently Ivermectin has been reported to have a role in the treatment of postCovid-19 syndrome (long haulers).[263] The anti-inflammatory properties of ivermectin may mediate this benefit.

c. Post-COVID-19 pulmonary fibrosis. An unknown number of patients who have recovered from COVID-19 organizing pneumonia will develop pulmonary fibrosis with associated limitation of activity. These patients should be referred to a pulmonologist with expertise in pulmonary fibrosis. Anti-fibrotic therapy may have a role in these patients, [238-241] however additional data is required before this therapy can be more generally recommended. 
29. Maintaining mental health and the avoiding the misinformation pandemic

'Misinformation on the Coronavirus might be the most contagious thing about it"

Dr. Tedros, WHO Director General

- The Panic and misinformation spread by Social Media travels faster than the pandemic itself. What you can do?

- Avoid social media as much as possible; excess social media exposure increases the likelihood of anxiety and depression[264]

- Read the news/information from reliable sources (if you can find one)

- Have a designated time for checking information

- People share false claims about COVID-19 partly because they simply fail to think sufficiently about whether or not the content is accurate when deciding what to share. [265]

- Stay connected to positive people! Remotely!

- Have a plan for staying in touch with family and friends

- Identify positive influencers... limit contact with other "worriers"

- Isolation can cause rumination/anxious thinking to escalate

- Maintain a sense of hope, humanity and kindness toward others

- Seek professional help if anxiety is overwhelming

- Recognize the things you can control

- WEAR A MASK when in contact with others

- Establish social distancing; stand/sit about 6 feet away from others

- Limit attendance at large gatherings

- Eliminate your contact with those who are ill

- DON'T go to work or school if you are sick

- Practice self-care

- Good sleep, balanced diet, exercise

- Mindfulness/Meditation/Relaxation activities

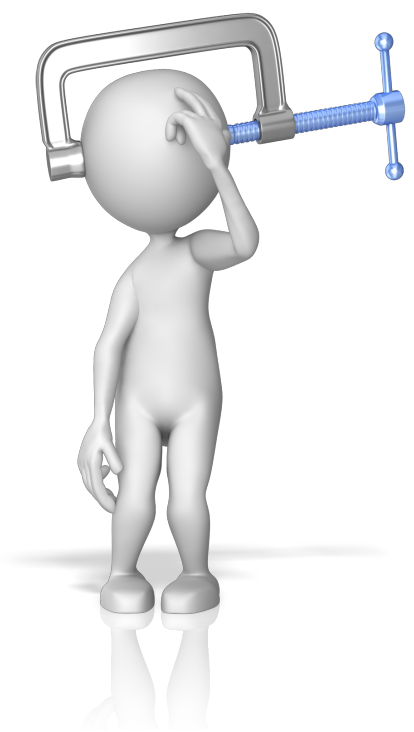




\section{Key Concepts of the FLCCC Alliance Treatment Protocol}

This is a very complex disease; many of the mysteries are still unravelling. However, a number of concepts are key to the management of this "treatable disease; they include.

1. Patients transition through a number of different phases (clinical stages). The treatment of each phase is distinct ... this is critically important (see Figures $1 \& 2$ ).

2. Antiviral therapy is likely to be effective only during the viral replicative phase whereas antiinflammatory therapy is expected to be effective during the pulmonary phase and possibly the post-COVID-19 phase. While Remdesivir is a non-specific antiviral agent that targets RNA viruses, it is likely that agents specifically designed to target SARS-CoV-2 will be developed.

3. The SARS-CoV-2 PCR remains positive for at least 2 weeks following detection of whole virus (by culture, See figure 3). Patients who progress to the pulmonary phase are usually PCR positive despite cessation of viral replication (and are therefore less likely to be infectious).

4. Due to the imperfect sensitivity of the PCR test as many as $20 \%$ of patients who progress to the pulmonary phase will be PCR negative (even on repeat testing). At symptom onset PCR will be positive in approximately $60 \%$ of patients; maximal positivity rate is on day 8 (post infection) when $80 \%$ of patients will be positive (see Figure3). [266]

5. Symptomatic patients are likely to be infectious during a narrow window starting 2-3 days before the onset of symptoms and to up to 6 days after the onset of symptoms (see Figure 3).[267]

6. It is important to recognize that COVID-19 patients present with a variety of phenotypes, likely dependent on inoculum size and viral load, genetic heterogeneity mutations and polymorphisms, biotypes, blood type, sex and androgen status, age, race, BMI (obesity), immunological and nutritional status, and co-morbidities.[149,268-278] The phenotype at presentation determines the prognosis and impacts the optimal approach to treatment.

7. The pulmonary phase is characterized by immune dysregulation, $[235,237,244,247,248,271$, 279-288] a pulmonary microvascular injury (vasculopathy),[244,288-291] with activation of clotting and a pro-coagulant state together with the characteristics of an organizing pneumonia. $[292,293]$

8. Endothelial damage and an imbalance of both innate and adaptive immune responses, with aberrant macrophage activation, plays a central role in the pathogenesis of the severe COVID-19 Disease. [244]

9. As patients, progress down the pulmonary cascade the disease becomes more difficult to reverse. The implications of this are twofold.

a. Early treatment (of the pulmonary phase) is ESSENTIAL to a good outcome.

b. Treatment in the late pulmonary phase may require escalation of the dose of corticosteroids as well as the use of salvage methods (i.e. plasma exchange). However, patients who present in the late pulmonary phase may have progressed to the irreversible pulmonary fibroproliferative phase (see Figure 9).

10. The pulmonary phase of COVID-19 is a treatable disease; it is inappropriate to limit therapy to "supportive care" alone. Furthermore, it is unlikely that there will be a single "silver bullet" to treat severe COVID-19 disease. Rather, patients will require treatment with multiple drugs/interventions that have synergistic and overlapping biological effects. Repurposed FDA approved drugs that are safe, inexpensive, and "readily" available are likely to have a major therapeutic effect on this disease. The impact of COVID-19 on middle- and low-income countries is enormous; these countries are not able to afford expensive propriety "designer" molecules.

11. The radiographic and pathological finding of COVID-19 lung disease are characteristic of a secondary organizing pneumonia (and not ARDS). [292,294,295] 
12. THIS is NOT ARDS (at least initially). The initial pulmonary phase neither looks like, smells like nor is ARDS.[296-298] The ground glass infiltrates are peripheral and patchy, [294] and do not resemble the dependent air space consolidation (sponge/baby lung) seen with "typical ARDS".[299] Extravascular lung water index (EVLWI) is normal or only slightly increased; this by definition excludes non-cardiogenic pulmonary edema (ARDS). Lung compliance is normal (this excludes ARDS). Patients are PEEP unresponsive. Treating patients as if they ARDS is a very dangerous approach. The hypoxia is due to severe ventilation/perfusion mismatch likely due to the microvascular narrowing, thrombosis and vasoplegia.

13. The core principles of the pulmonary phase $(\mathrm{MATH}+)$ is the use of anti-inflammatory agents to dampen the "cytokine storms" together with full anticoagulation to limit the microvascular and macrovascular clotting and supplemental oxygen to help overcome the hypoxia.

14. Ivermectin has emerged as the "wonder drug" to prophylaxis and treat COVID-19. Ivermectin inhibits viral replication and has potent anti-inflammatory properties. Emerging clinical data (including RCT's) suggest that ivermectin may have an important clinical benefit across the spectrum of phases of the disease, i.e pre-exposure prophylaxis, postexposure prophylaxis, during the symptomatic phase and during the pulmonary phase. $[1-5,62,64-74][1-3,64,67-$ 74,129-131,177-184] In the recommended dosages, Ivermectin is remarkably safe (see Table 1 and Fig 5). However, as noted above there is the potential for serious drug-drug interaction. Additional, studies are urgently required to confirm these very impressive preliminary findings.

15. The pulmonary phase of COVID-19 is characterized by PROLONGED immune dysregulation that may last weeks or even months. The early and abrupt termination of anti-inflammatory agents will likely result in rebound inflammation (see Figure 8).[300]

16. SARS-CoV-2 as compared to all other respiratory viruses, upregulates cytokines and chemokines while at the same time down regulating the expression of Interferon alpha (the hosts primary antiviral defence mechanism). [131,155] Low innate antiviral defenses and high proinflammatory mediators contribute to ongoing and progressive lung injury.

17. Patients in whom the cytokine storm is not "dampened" will progress into the "H phenotype" characterized by poor lung compliance, severe oxygenation failure and PEEP recruitability (see Figure 9). Progression to this phase is exacerbated by ventilator induced lung injury (VILI). The histologic pattern of the "H Phenotype" is characterized by an acute fibrinous and organizing pneumonia (AFOP), with extensive intra-alveolar fibrin deposition called fibrin "balls" with absent or minimal hyaline membranes.[273,295,301-303] Corticosteroids seem to be of little benefit in established AFOP. High dose methylprednisolone should be attempted in the "early phase" of AFOP, however many patients will progress to irreversible pulmonary fibrosis with prolonged ventilator dependency and ultimately death.

18. An unknown percentage of patients with COVID-19 present with "silent hypoxia" with a blunted respiratory response. This phenomenon may be related to involvement of chemoreceptors of the carotid bodies and/or brain stem dysfunction,[304,305] and necessitates pulse oximetry in symptomatic patients managed at home (as discussed above).

19. It should be recognized that LWMH has non-anticoagulant properties that are likely beneficial in patients with COVID-19, these include anti-inflammatory effects and inhibition of histones.[306] in addition, in vitro studies demonstrate that heparin inhibits SARS-CoV-2 interaction with the ACE-2 receptor and viral entry,[307,308] as well as viral replication $[72,133]$. Most importantly LWWH inhibits heparanase (HPSE).[309] HSE destroys the endothelial glycocalyx increasing endothelial leakiness, activating clotting and potentiating endothelialitis.[309] HPSE levels have been reported to be increased in patients with severe COVID-19 infection. [310]

20. Due to the ease of administration, greater anti-Xa activity and better safety profile we prefer low molecular weight heparin (LMWH) to unfractionated heparin (UFH). 
21. The combination of steroids and ascorbic acid (vitamin $C$ ) is essential. Both have powerful synergistic anti-inflammatory actions. $[165,173]$ Vitamin $C$ protects the endothelium from oxidative injury.[166,311-313] Furthermore, vitamin C Increases the expression of interferonalpha [26] while corticosteroids (alone) decease expression of this important protein. [314317] It should be noted that when corticosteroids are used in the pulmonary phase (and not in the viral replicative phase) they do not appear to increase viral shedding or decrease the production of type specific antibodies. [151,318] It is likely that heparin (LMWH) acts synergistically with corticosteroids and vitamin $C$ to protect the endothelium and treat the endothelialitis of severe COVID-19 disease.

22. Notwithstanding the very important and impressive results of the Recovery-Dexamethasone study, methylprednisolone is the corticosteroid of choice for the pulmonary phase of COVID-19. This is based on pharmacokinetic data (better lung penetration),[319] genomic data specific for SARS-CoV-2,[320] and a long track record of successful use in inflammatory lung diseases. (see Table 1)

23. For prophylaxis and treatment of the early symptomatic phase we suggest the combination of Quercetin (a plant polyphenol), Vitamin C and Zinc. This is based on intriguing basic science data which indicates that:

a. Zinc is essential for innate and adaptive immunity.[52] In addition, Zinc inhibits RNA dependent RNA polymerase in vitro against SARS-CoV-2 virus.[51]

b. Quercetin has direct viricidal properties against a range of viruses, including SARS-CoV2 , and is a potent anti-oxidant and anti-inflammatory agent. [24,29,34,34,321-328] In addition, quercetin acts as a zinc ionophore. [329]

c. Vitamin C improves the potency of Quercetin and has antiviral and anti-inflammatory activity.[24]

24. It should also be noted that Vitamin D may be a very powerful prophylactic and treatment strategy against COVID-19. Vitamin D deficiency explains, in part, the enormous geographic variation in mortality of this disease. [11,330]

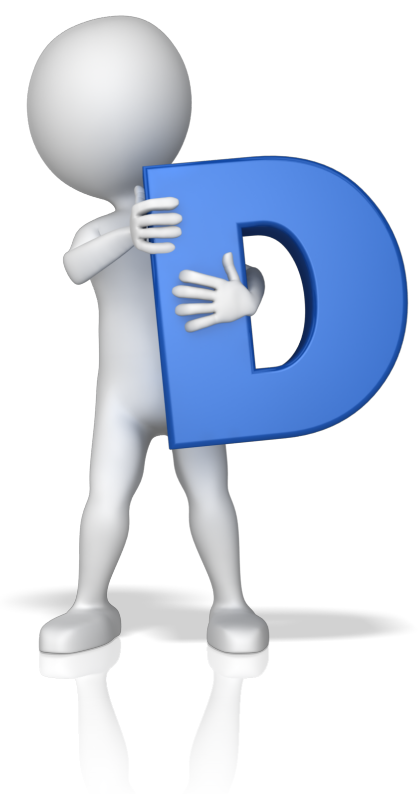


Figure 9. The consequences of "steroid" avoidance". CT scan after 23 days of "supportive care" demonstrating the late fibroproliferative (irreversible) phase of COVID-19 lung disease (Image kindly provide by Dr. Pierre Kory, from NYC).

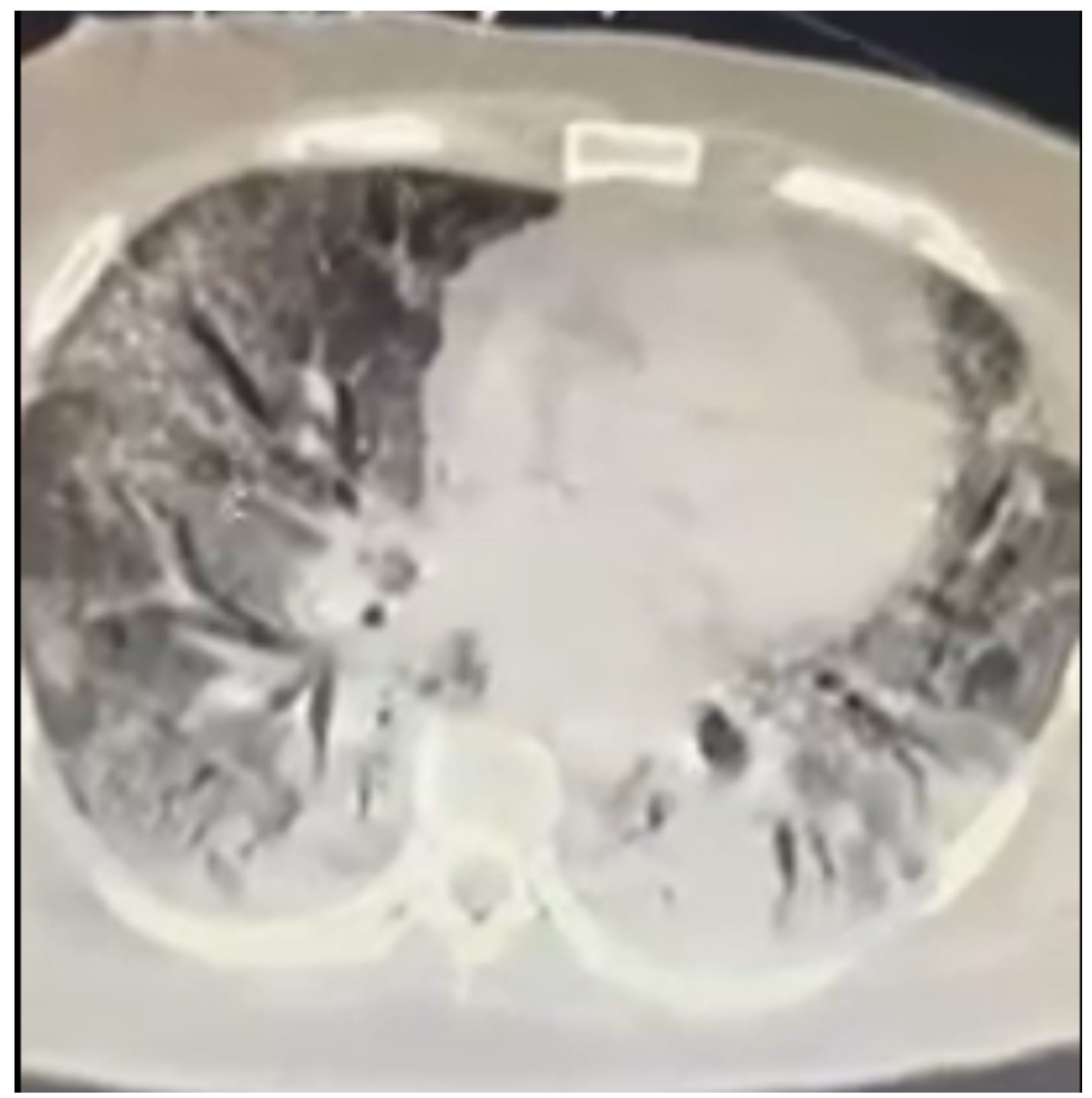




\section{Scientific Rationale for MATH+ Treatment Protocol (pulmonary phase)}

Three core pathologic processes lead to multi-organ failure and death in COVID-19:

1) Hyper-inflammation ("Cytokine storm") - a dysregulated immune system whose cells infiltrate and damage the lungs as well as other organs including the heart and bone marrow. It is now widely accepted that SARS-CoV-2 causes aberrant T lymphocyte and macrophage activation resulting in a "cytokine storm." [235,237,247,248,271,279,281-287] In addition, post-mortem examination has demonstrated features of the "macrophage activation syndrome", with hemophagocytosis and a hemophagocytic lymphohistiocytosis-like disorder.[244]

2) Hyper-coagulability (increased clotting) - the dysregulated immune system damages the endothelium and activates blood clotting, causing the formation of micro and macro blood clots. Clotting activation may occur directly due to increased expression of Factor Xa as well as endothelial injury with the release of large aggregates of van Willebrand factor.[77] These blood clots impair blood flow. [134,135,137-145,290,291,331,332] It should be noted that the thrombotic microangiopathy appears to target predominantly the pulmonary and cerebral circulation. [244]

3) Severe Hypoxemia (low blood oxygen levels) -lung inflammation caused by the cytokine storm, together with microthrombosis in the pulmonary circulation severely impairs oxygen absorption resulting in oxygenation failure.

The above pathologies are not novel, although the combined severity in COVID-19 disease is considerable. Our long-standing and more recent experiences show consistently successful treatment if traditional therapeutic principles of early and aggressive intervention is achieved, before the onset of advanced organ failure. It is our collective opinion that the historically high levels of morbidity and mortality from COVID-19 is due to a single factor: the widespread and inappropriate reluctance amongst hospitalists and intensivists to employ anti-inflammatory and anticoagulant treatments, including corticosteroid therapy early in the course of a patient's hospitalization. It is essential to recognize that it is not the virus that is killing the patient, rather it is the patient's overactive immune system.

$[234,237,244,305]$ Autopsy studies have demonstrated minimal viral cytopathic effects.[244,305] The flames of the "cytokine fire" are out of control and need to be extinguished. Providing supportive care (with ventilators that themselves stoke the fire) and waiting for the cytokine fire to burn itself out simply does not work... this approach has FAILED and has led to the death of tens of thousands of patients.

\section{"If what you are doing ain't working, change what you are doing" - PEM}

The systematic failure of critical care systems to adopt corticosteroid therapy (early in this pandemic) resulted from the published recommendations against corticosteroids use by the World Health Organization (as recent as May $27^{\text {th }} 2020$ ) $[333,334]$. This recommendation was then perpetuated by the Centers for Disease Control and Prevention (CDC), the American Thoracic Society (ATS), Infectious Diseases Association of America (IDSA) amongst others. A publication authored one of the members of the Front Line COVID-19 Critical Care (FLCCC) Alliance (UM), identified the errors made by these organizations in their analyses of corticosteroid studies based on the findings of the SARS and H1N1 pandemics.[146,335] Their erroneous recommendation to avoid corticosteroids in the treatment of COVID-19 has led to the development of myriad organ failures which have overwhelmed critical care systems across the world and led to excess deaths. The recently published results of the RECOVERYDEXAMETHASONE study provide definitive and unambiguous evidence of the lifesaving benefits of corticosteroids and strong validation of the MATH + protocol. It should be recognized that corticosteroids are the only therapy proven to reduce the mortality in patients with COVID-19.[336] The 
RECOVERY-DEXAMETHASONE study, randomized 2104 patients to receive dexamethasone $6 \mathrm{mg}$ (equivalent to $32 \mathrm{mg}$ methylprednisolone) once per day (either by mouth or by intravenous injection) for ten days and were compared with 4321 patients randomized to usual care alone.[123] Dexamethasone reduced deaths by one-third in ventilated patients (rate ratio 0.65 [95\% confidence interval 0.48 to 0.88 ]; $p=0.0003$ ) and by one fifth in other patients receiving oxygen only ( 0.80 [0.67 to $0.96] ; p=0.0021)$. There was no benefit among those patients who did not require respiratory support (1.22 [0.86 to 1.75; $p=0.14$ ). The results of this study STRONGLY support the EVMS/MATH+ protocol which recommends the use of corticosteroids for the "pulmonary phase" of COVID-19. It should be noted that we would consider the non-titratable "fixed" dose of dexamethasone used in the RECOVERYDEXAMETHASONE study to be very low. Furthermore, as indicated above we consider methylprednisolone to be the corticosteroid of choice for the treatment of COVID-19 pulmonary disease. The benefit of methylprednisolone in improving respiratory function, ventilator dependency and mortality has been confirmed in a number of observational studies, [147,148,154,318,337-339] as well as a randomized controlled study.[156] It should be recognized that the mortality benefit with methylprednisolone was not replicated in a recent Brazilian RCT. [300] However, in this study methylprednisolone was started relatively late (day 13 after symptom onset), but most importantly was stopped on day 5 . This failed study reinforces the concept of early and prolonged treatment with methylprednisolone titrated to the patient's clinical response. In patients at high risk of Strongyloides infection, screening and/or treatment of this parasite with ivermectin is suggested prior to treatment with corticosteroids.[340]

Our treatment protocol targeting the key pathologic processes has been highly successful, if begun within 6 hours of a COVID19 patient presenting with shortness of breath and/or arterial desaturation and requiring supplemental oxygen. If such early initiation of treatment could be systematically achieved, the need for mechanical ventilators and ICU beds will decrease dramatically.

\section{Further resources:}

The reader is referred to the large autopsy series by Bruce and colleagues which clearly outlines the pathophysiology of severe COVID-19 disease.[244]

The scientific rationale for the MATH + protocol is reviewed in this paper.[163]

In this U-tube video, Professor Britt Glaunsinger, PhD provides an outstanding review on the molecular virology of SARS-CoV-2: https://www.youtube.com/watch?v=DQVpHyvz4no

Lectures by Paul Marik, MD reviewing clinical aspects of COVID-19.

https://www.youtube.com/channel/UCz9Pvn15m4Rv1uY-aBYRVuw

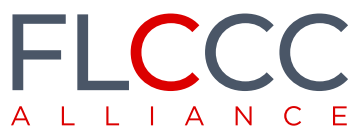

FRONT LINE COVID-19 CRITICAL CARE ALLIANCE PROPHYLAXIS \& TREATMENT PROTOCOLS FOR COVID-19 


\section{References}

1. Gorial FI, Mashhadani S, Sayaly HM, Dakhil BD, AIMashhadani MM. Effectiveness of Ivermectin as add-on therapy in COVID-19 management (Pilot Trial). medRxiv 2020.

2. Khan MS, Khan MS, Debnath $\mathrm{Cr}$, Nath PN, Mahtab MA. Ivermectin treatment may improve the prognosis of patients with COVID-19. Archivos de Bronconeumologia 2020.

3. Rajter JC, Sherman MS, Fatteh N, Vogel F, Sacks J, Rajter JJ. ICON (Ivermectin in COvid Ninteen) study: Use of ivermectin is associated with lower mortality in hospitalized patients with COVID-19. Chest 2020.

4. Niaee MS, Gheibl N, Namdar P, Allami A, Javadi A. Ivermectin as an adjunct treatment for hospitalized adult COVID-19 patients: A randomized multi-center clinical trial. Research Square 2020.

5. Elgazzar A, Hany B, Youssef SA, Hany B, Hafez M. Efficacy and safety of ivermectin for treatment and prophylaxis of COVID-19 pandemic. Research Square 2020.

6. Hashim HA, Maulood MF, rasheed AM, Fatak DF, Kabah KK. Controlled randomized clinical trial on using Ivermectin with Doxycycline for treating COVID-19 patients in Bagdad, Iraq. medRxiv 2020.

7. Maghbooli Z, Sahraian MA, Ebrahimi M, Pazoki M, Kafan S. Vitamin D sufficiency, a serum 25hydroxyvitamin $D$ at least $30 \mathrm{ng} / \mathrm{ml}$ reduced risk for adverse clinical outcomes in patients with COVID-19 infection. PloS ONE 2020; 15:e0239799.

8. Grant WB, Lahore H, McDonnell SL, Baggerly CA, French Cb, Aliaono JL. Evidence that Vitamin D supplementation could reduce risk of influenza and COVID-19 infections and deaths. Nutrients 2020; 12:988.

9. Kaufman HW, Niles JK, Kroll MH, Bi C, Holick MF. SARS-CoV-2 positivity rates associated with circulating 25-hydroxyvitamin D level. PloS ONE 2020; 15:e0239252.

10. Lau FH, Majumder R, Torabi R, Saeg F, Hoffman R, Cirillo JD. Vitamin D insufficiency is prevalent in severe COVID-19. medRxiv 2020.

11. Marik PE, Kory P, Varon J. Does vitamin D status impact mortlality from SARS-CoV-2 infection? Medicine in Drug Discovery 2020.

12. Rhodes JM, Subramanian S, Laird E, Kenny RA. Editorial: Low population mortality from COVID-19 in countries south of 35 degrees North - supports vitamin $D$ as a factor determining severity. Alimentary Pharmacology \& Therapeutics 2020; (in press).

13. Dancer RC, Parekh D, Lax $\mathrm{S}$ et al. Vitamin $\mathrm{D}$ deficiency contributes directly to the acute respiratory distress syndrome (ARDS). Thorax 2015; 70:617-24.

14. LLie PC, Stefanescu S, Smith L. The role of vitamin D in the prevention of coronavirus disease 2019 infection and mortality. Aging Clin Exp Res 2020.

15. Daneshkhah A, Eshein A, Subramanian H. The role of vitamin D in suppressing cytokine storm of COVID-19 patients and associated mortality. medRxiv 2020.

16. Bergman $P$, Lindh AU, Bjorkhem-Bergman L, Lindhagen L. Vitamin D and respiartory tract infections: A systematic review and meta-analysis of randomized controlled trials. PloS ONE 2013; 8:e65835.

17. Carpagnano GE, Lecce V, Quaranta VN, Zito A, Buonamico E. Vitamin D deficiency as a predictor of poor prognosis in patients with acute respiratory fialure due to COVID-19. J Endocrinol Invest 2020.

18. Israel A, Cicurel A, Feldhamer I et al. The link between vitamin D deficiency and Covid-19 in a large population. medRxiv 2020.

19. Radujkovic A, Hippchen T, Tiwari-Heckler S, Dreher S, Merle U. Vitamin D deficiency and outcome of COVID-19 patients. Nutrients 2020; 12:2757.

20. Rizzoli R. Vitamin D supplementation: upper limit for safety revisited. Aging Clin Exp Res 2020.

21. Annweiler C, Hanotte B, de L'Eprevier CG, Sabatier JM, Lafaie L. Vitamin D and survival in COVID-19 patients: A quasi-experimental study. Journal of Steroid Biochemistry \& Molecular Biology 2020.

22. Moozhipurath RK, Kraft L, Skiera B. Evidence of protective role of Ultraviolet-B (UVB) radiation in reducing COVID-19 deaths. Nature Research 2020; 10:17705.

23. Maggini S, Beveridge S, suter M. A combination of high-dose vitamin C plus zinc for the common cold. Journal of International Medical Research 2012; 40:28-42.

24. Colunga Biancatelli RM, Berrill M, Catravas JD, Marik PE. Quercetin and Vitamin C: experimental therapy for the prevention and treatment of SARS-CoV-2 via synergistic action. Front Immunol 2020.

25. Kyung Kim T, Lim HR, Byun JS. Vitamin C supplementaion reduces the odds of developing a common cold in Republic of Korea Army recruits: a randomised controlled trial. BMJ Mil Health 2020. 
26. Colunga Biancatelli RM, Berrill M, Marik PE. The antiviral properties of vitamin C. Expert Rev Anti Infect Ther 2020; 18:99-101.

27. Hiedra R, Lo KB, Elbashabsheh M, Gul F, Wright RM. The use of IV vitamin C for patients with COVID-19: a case series. Exp Rev Anti Infect Ther 2020.

28. Khaerunnisa S. Potential inhibitor of COVID-19 main protease (Mpro) from several medicinal plant compuns by molecular docking study. medRxiv 2020.

29. Chen L, Li J, Luo C, Liu H, Xu W, Chen G. Binding interaction of quercetin-3-B-galactoside and its synthetic derivatives with SARS-CoV $3 \mathrm{CL}$ : structure-activity relationship reveal salient pharmacophore features. Bioorganic \& Medicinal Chemistry Letters 2006; 14:8295-306.

30. Nain Z, Rana HK, Lio P, Islam SM, Summers MA, Moni MA. Pathogenic profiling of COVID-19 and SARS-like viruses. Briefings in Bioinformatics 2020.

31. Yi L, Li Z, Yuan K et al. Small molecules blocking the entry of severe respiratory syndrome coronavirus into host cells. J Virol 2020; 78:11334-9.

32. Shakoor H, Feehan J, Dhaheri AS, Ali HI, Platat C, Ismail LC. Immune-boosting role of vitamins D,C,E, zinc, selenium and omega-3 fatty acids: could they help against COVID-19. Maturitas 2020.

33. Calder PC. Nutrition, immunity and COVID-19. BMJ Nutrition, Prevenion \& Health 2020; 3.

34. Abian O, Ortega-Alarcon D, Jimenez-Alesanco A, Ceballos-Laita L, Vega S. Structural stability of SARS-CoV$23 \mathrm{CLpro}$ and identification of quercetin as an inhibitor by experimental screening. International Journal of Biological Macromolecules 2020; 164:1693-703.

35. Arslan B, Ergun NU, Topuz S, Semerci SY, Suner N. Synergistic effect of quercetin and vitamin C against COVID-19: Is a possible guard for front liners? ssrn 2020.

36. Giuliani C, Bucci I, Di Santo S, Rossi C, Grassadonia A, Piantelli M. The flavonoid quercetin in hibits thyroidrestricted genes expression and thyroid function. Food and Chemical Toxicology 2014; 66:23-9.

37. de Souza dos Santos MC, Goncalves CF, Vaisman M, Ferreira AC, de Carvalho DP. Impact of flavonoids on thyroid function. Food and Chemical Toxicology 2011; 49:2495-502.

38. Chandra AK, De N. Catechin induced modulation in the activities of thyroid hormone synthesizing enzymes leading to hypothyroidism. Mol Cell Biochem 2013; 374:37-48.

39. Pistollato F, Masias M, Agudo P, Giampieri F. Effects of phytochemicals on thyroid function and their possible role in thyroid disease. Ann N Y Acad Sci 2019; 1433:3-9.

40. Sathyapalan T, Manuchehri AM, Thatcher NJ, Rigby AS, Chapman T. The effect of soy phytoestrogen supplementation on thyroid status and cardiovascular risk markers in patients with subclinical hypothyroidism: A randomized, double-blind, crossover study. J Clin Endocrinol Metab 2020; 96:1422-49.

41. Tonstad S, Jaceldo-Siegl K, Messina M, Haddad E. The association between soya consumption and serum thyroid-stimulating hormone in the Adventist Health Study-2. Public Health Nutr 2016; 19:1464-70.

42. Colombo D, Lunardon L, Bellia G. Cyclosporine and herbal supplement interactions. Journal of Toxicology 2014; 2014:145325.

43. Colunga Biancatelli RM, Berrill M, Mohammed YH, Marik PE. Melatonin for the treatment of sepsis: the scientific rationale. J Thorac Dis 2020; 12 (Suppl 1):S54-S65.

44. Reiter RJ, Abreu-Gonzalez P, Marik PE, Dominguez-Rodriguez A. Therapeutic algorithm for use of melatonin in patients with COVID-19. Front Med 2020; 7:226.

45. Reiter RJ, Sharma R, Ma Q, Dominquez-Rodriguez A, Marik PE, Abreu-Gonzalez P. Melatonin inhibits COVID-19-induced cytokine storm by reversing aerobic glycolysis in immune cells: A mechanistic analysis. Medicine in Drug Discovery 2020; 6:100044.

46. Zhang R, Wang X, Ni L, Di X, Ma B. COVID-19: Melatonin as a potential adjuvant treatment. Life Sci 2020; 250:117583.

47. Jehi L, Ji X, Milinovich A, erzurum S, Rubin B, Gordon S. Individualizing risk prediction for positive COVID19 testing. Results from 11,672 patients. Chest 2020.

48. Kleszczynski K, Slominski AT, Steinbrink K, Reiter RJ. Clinical trials for use of melatonin to fight COVID-19 are urgently needed. Nutrients 2020; 12.

49. Coto-Montes A, Boga JA. ER stress and autophagy induced by SARS-CoV-2: The targer for melatonin treatment. Melatonin Res 2020; 3:346-61.

50. Gandolfi JV, Di Bernardo AP, Chanes DA et al. The effects of melatonin supplementation on sleep quality and assessment of the serum melatonin in ICU patients: A randomized controlled trial. Crit Care Med 2020. 
51. te Velthuis AJ, van den Worm SH, Sims AC, Baric RS, Snijder EJ, van Hemert MJ. Zn2+ inhibits Coronavirus and Arterivirus RNA polymerase activity In Vitro and Zinc ionophores block the replication of these viruses in cell culture. PLos Pathog 2010; 6:e1001176.

52. Gammoh NZ, Rink L. Zinc in Infection and Inflammation. Nutrients 2017; 9.

53. Hemila H. Zinc lozenges and the common cold: a meta-analysis comparing zinc acetate and zinc gluconate, and the role of zinc dosage. J Royal Soc Med Open 2017; 8:1-7.

54. Singh M, Das RR. Zinc for the common cold. Cochrane Database of Syst Rev 2013; 6:CD001364.

55. Hoeger J, Simon TP, Beeker T, Marx G, Haase H. Persistent low serum zinc is associated with recurrent sepsis in critically ill patients - A pilot study. PloS ONE 2017; $12:$ e0176069.

56. Shakoor H, Freehan J, Mikkelsen K, Al Dhaheri AS, Ali HI. Be well: A potential role for vitamin B in COVID19. Maturitas 2020.

57. dos Santos LM. Can vitamin B12 be an adjuvant to COVID-19 treatment? GSC Biological and Pharmaceutical Sciences 2020; 11.

58. Kandeel M, Al-Nazawi M. Virtual screening and repurposing of FDA approved drugs against COVID-19 main protease. Life Sci 2020; 251:117627.

59. Tan CW, Ho LP, Kalimuddin S, Cherng BP, Teh YE. Cohort study to evaluate effect of vitamin D, magnesium, and vitamin b12 in combination on severe outcome progression in older patients with coronavirus (COVID-19). Nutrition 2020; 80:111017.

60. Zhang P, Tsuchiya K, Kinoshita T, Kushiyama H, Suidasari S, Hatakeyama M. Vitamin B6 prevents IL-1B protein production by inhibiting NLRP3 inflammasome activation. J Biol Chem 2020; 291:24517-27.

61. Behera P, Patro BK, Singh AK, Chandanshive PD, Kumar R. Role of ivermectin in the prevention of COVID19 infection among healthcare workers in India: A matched case-control study. medRxiv 2020.

62. Kory P, Meduri GU, Iglesias J et al. Review of the emerging evidencce supporting the use of Ivermectin in the prophylaxis and treatment of COVID-19. Front Line Covid-19 Critical Care Alliance. osf io 2020.

63. Castillo ME, Costa LM, Barrios JM et al. Effect of calcifediol treatment and best available therapy versus best available therapy on intensive care unit admission and mortality among patients hospitalized for COVID-19: a pilot randomized clinical study. J Steroid Biochem Mol Biol 2020.

64. Hashim HA, Maulood MF, rasheed AM, Fatak DF, Kabah KK. Controlled randomized clinical triaal on using Ivermectin with Doxycycline for treating COVID-19 patients in Bagdad, Iraq. medRxiv 2020.

65. Alam MT, Murshed R, Bhiuyan E, Saber S, Alam RF, Robin RC. A case series of 100 COVID-19 positive patients treated with combination of Ivermectin and Doxycycline. Bangladesh Coll Phys Surg 2020; 38:105.

66. Chowdhury AT, Shahabz M, Karim MR, Islam J, Guo D, He D. A randomized trial of ivermectin-doxycycline and hydrochloroquine-azithromycin therapy on COVID-19 patients. Research Square 2020.

67. Chamie J. Real-World evidence: The case of Peru, casuality between Ivermectin and COVID-19 infection fatality rate. ResearchGate 2020.

68. Caly L, Druce JD, Catton MG, Jans DA, Wagstaff KM. The FDA-approved drug Ivermectin inhibits the replication of SARS-CoV-2 in vitro. Antiviral Res 2020.

69. Lehrer S, Rheinstein PH. Ivermectin docks to the SARS-CoV-2 spike receptor-binding domain attached to ACE2. In Vivo 2020; 34:3023-6.

70. Maurya DK. A combination of Ivermectin and Doxycycline possibly blocks the viral entry and modulate the innate immune response in COVID-19 patients. ChemRxiv 2020.

71. Yang SN, Atkinson SC, Wang C, Lee A. The broad spectrum antiviral ivermectin targets the host nuclear transport importin alpha/beta1 heterodimer. Antiviral Res 2020; 177:104760.

72. Dayer MR. Coronavirus (2019-nCoV) deactivation via spike glycoprotein shielding by old drugs, bioinformatic study. Preprints 2020.

73. Swargiary A. Ivermectin as a promising RNA-dependent RNA polymerase inhibitor and a therapeutic drug against SARS-CoV2: Evidence from silico studies. Research Square 2020.

74. Kircik LH, Del Rosso JQ, Layton AM, schauber J. Over 25 years of clinical experience with Ivermectin: An overview of safety for an increasing number of indications. J Drugs Dermatol 2016; 15:325-32.

75. Bianconi V, Violi F, Fallarino F, Pignatelli P, Sahebkar A, Pirro M. Is acetylsalicylic acid a safe and potentially useful choice for adult patients with COVID-19? Drugs 2020.

76. Muller C, Karl N, Ziebuhr J, Pleschka S. D,L-lysine acetylsalicylate + glycine impairs coronavirus replication. J Antivir Antiretovir 2020. 
77. Varatharajah N. COVID-19 CLOT: What is it? Why in the lungs? Extracellular histone, "auto-activation" of prothrombin, emperipolesis, megakaryocytes, "self-association" of Von Willebrand factor and beyond. Preprints 2020.

78. Freedberg DE, Conigliaro J, Sobieszczyk ME, Markowitz DD. Famotidine use is associated with impoved clinical outcomes in hospitalized COVID-19 patients: A propensity score matched retrospective cohort study. medRxiv 2020.

79. Janowitz T, Baglenz E, Pattinson D, Wang TC, Conigliaro J. Famotidine use and quantitative symptom tracking for COVID-19 in non-hospitalized patients: a case series. Gut 2020; 69:1592-7.

80. Mather JF, Seip RL, McKay RG. Impact of famotidine use on clinical outcomes of hospitalized COVID-19 patients. Am J Gastroenterol 2020.

81. Malone RW, Tisdall P, Fremont-Smith P, Liu Y, Huang XP, White KM. COVID-19: Famotidine, Histamine, Mast Cells, and mechanisms. Research Square 2020.

82. Sethia R, Prasad M, Mahapatra SJ, Nischal N, Soneja M. Efficacy of famotidine for COVID-19: A systematic review and meta-analysis. medRxiv 2020.

83. Shoaibi A, Fortin S, Weinstein R, Berlin JA. Comparative effectiveness of famotidine in hospitalized COVID19 patients. medRxiv 2020.

84. Yeramaneni S, Doshi P, Sands K, Cooper M, Kurbegov D, Fromell G. Famotidine use is not associated with 30-day mortality: A coarsened exact match study in 7158 hospitalized COVID-19 patients from a large healthcare system. medRxiv 2020.

85. Hammock BD, Wang W, Gilligan MM, Panigrahy D. Eicosanoids. The overlooked storm in Coronavirus Disease 2019 (COVID-19)? Am J Pathol 2020.

86. Das UN. Can bioactive lipids inactivate coronavirus (COVID-19)? Arch Med Res 2020; 51:282-6.

87. Lee $\mathrm{CR}$, Zeldin DC. Resolvin infectious inflammation by targeting the host response. N Engl J Med 2015; 373:2183-5.

88. Serhan $\mathrm{CN}$. Novel pro-resolving lipid mediators in inflammation are leads for resolution physiology. Nature 2014; 510:92-101.

89. Idelsis Esquivel-Moynelo I, Perez-Escribano J, Duncan-Roberts $Y$, Dania Vazquez-Blonquist D. Effect of combination of interferon alpha- $2 b$ and interferon-gamma or interferon alpha $2 b$ alone for elimination of SARS-CoV-2 viral RNA. Preliminary results of a randomized controlled clinical trial. medRxiv 2020.

90. Davoudi-Monfarad E, Rahmani H, Khalili H, Hajiabdolbaghi M, Salehi M. Efficacy and safety of interferon B-1a in treatment of severe COVID-19: A randomized clinical trial. medRxiv 2020.

91. Wang N, Zhan Y, Zhu L, Hou Z, Liu F, Song P. Retrospective multicenter cohort study shows early interferon therapy is associated with favorable clinical responses in COVID-19 patients. Cell Host \& Microbe 2020; ePub.

92. Meng Z, Wang T, Chen L, Chen X, Li L. An experimental trial of recombinant human interferon alpha nasal drops to prevent COVID-19 in medical staff in an epidemic area. medRxiv 2020.

93. Berg K, Bolt G, Andersen H, Owen TC. Zinc potentiates the antiviral action of human IFN-alpha tenfold. J Interferon Cytokine Res 2001; 21:471-4.

94. Cakman I, Kirchner H, Rink L. Zinc supplementation reconstitutes the production of interferon-alpha by leukocytes from elderly persons. J Interferon Cytokine Res 1997; 17:469-72.

95. Luks AM, Swenson ER. Pulse oximetry for monitoring patients with COVID-19 at home: Potential pitfalls and practical guidance. Ann Thorac Med 2020.

96. Jouffroy R, Jost D, Prunet B. Prehospital pulse oximetry: a red flag for early detection of silent hypoxemia in COVID-19 patients. Crit Care 2020; 24:313.

97. Risch HA. Early outpatient treatment of symptomatic, High-Risk Covid-19 patients that should be rampedup immediately as key to the pandemic crisis. Am J Epidemiol 2020.

98. Borba MG, Val FF, Sampaio S. Effect of High vs Low Doses of chloroquine diphosphate as adjunctive therapy for patietns hospitalized with severe acute respiratory syndrome coronavirus 2 (SARS-CoV-2) infection. A randomized clinical trial. JAMA Network Open 2020.

99. Boulware DR, Pullen MF, Bangdiwala AS, Pastick KA. A randomized trial of hydroxychloroquine as postexposure prophylaxis for Covid-19. N Engl J Med 2020.

100. Mitja O, Corbacho-Monne M, Ubals M, Tebe C, Penafiel J. Hydroxychloroquine for early treatment of adults with mild Covid-19: A randomized-controlled trial. Clin Infect Dis 2020.

101. Mitja O, Ubals M, Corbach-Monne M, Alemany A, Suner C. A cluster-randomized trial of hydroxychloroquine as prevention of Covid-19 transmission and disease. N Engl J Med 2020. 
102. Cavalcanti AB, Zampieri FG, Rosa RG, Azevedo LC, Veiga VC, Avezum A. Hydroxychloroquine with or without azithromycin in mild-to-moderate Covid-19. N Engl J Med 2020; 383:2041-52.

103. Skipper CP, Pastick KA, Engen NW. Hydroxychlooquine in nonhospitalized adults with early COVID-19. Ann Intern Med 2020; 173:623-31.

104. Rosenberg ES, Dufort EM, Udo T, Wilberschied LA. Association of treatment with hydroxychloroquine or azithromycin with in-hospital mortality in patients with COVID-19 in New York State. JAMA 2020; 323:2493-502.

105. Geleris J, Sun Y, Platt J, Zucker J. Observational study of hydroxychloroquine in hospitalized patients with Covid-19. N Engl J Med 2020.

106. Magagnoli J, Narendran S, Pereira F. Outcomes of hydroxychloroquine usage in United states veterans hospitalized with COVID-19. medRxiv 2020.

107. Lopez A, Duclos G, Pastene B, Bezulier K, Guihaumou R, Solas C. Effects of hydroxychloroquine on Covid19 in Intensive Care Unit Patients: Preliminary Results. Int J Antimicrob Agents 2020.

108. Mahevas M, Tran VT, Roumier M, Chabrol A, Paule R. No evidence of clinical efficacy of hydroxychloroquine in patients hospitalized for COVID-19 infection and requiring oxygen: results of a study using routinely collected data to emulate a target trial. medRxiv 2020.

109. Elsawah HK, Elsokary MA, Elrazzaz MG, ElShafey MG. Hydroxychloroquine for treatment of non-severe COVID-19 patients: systematic review and meta-analysis of controlled clinical trials. medRxiv 2020.

110. Axfors C, Schmitt AM, Janiaud P, van 't Hooft J, Abd_elsalam S, Abdo EF. Mortality outcomes with hydroxychloroquine and chloroquine in COVID-19: an international collaborative meta-analysis of randomized trials. medRxiv 2020.

111. Sbidian $\mathrm{E}$, Josse J, Lemaitre $\mathrm{G}$ et al. Hydroxychloroquine with or without azithromycin and in-hospital mortality or discharge in patients hospitalized for COVID-19 infection: a cohort study of 4,642 in-patients in France. medrx 2020.

112. Effect of hydroxychloroquine in hospitalized patients with COVID-19. N Engl J Med 2020; 383:2030-40.

113. Abd-Elsalam S, Esmail ES, Khalaf M, Abdo EF, Medhat MA. Hydroxychloroquine in the Treatment of COVID-19: A Multicenter Randomized Controlled Study. Am J Trop Med Hyg 2020; 103:1635-9.

114. Rajasingham R, Bangdiwala AS, Nicol MR, Skipper CP, Pastick KA. Hydroxychloroquine as pre-exposure prophylaxis for COVID-19 in healthcare workers: a randomized trial. medRxiv 2020.

115. Self WE, Semler MW, Leither Lm et al. Effect of hydroxychloroquine on clinical status at 14 days in hospitalized patients with COVID-19. a randomized clinical trial. JAMA 2020.

116. Tett SE, Cutler DJ, Day RO, Brown KF. Bioavailability of hydroxychloroquine tablets in healthy volunteers. Br J Clin Pharmac 1989; 27:771-9.

117. MacGowan A, Hamilton F, Bayliss M, Read L, Attwood M. Hydroxychloroquine serum concentrations in non-critical care patients infected with SARS-CoV-2. medRxiv 2020.

118. Nicol MR, Joshi A, Rizk ML, Sabato PE, Savic RM. Pharmacokinetic and pharmacological properties of chloroquine and hydroxychloroquine in the context of COVID-19 infection. medRxiv 2020.

119. Gautret $P$, Lagier JC, Parola P, Hoang VT. Hydroxychloroquine and azithromycin as a treatment of COVID19: results of an open-label non-randomized clinical trial. Int J Antimicrob Agents 2020.

120. Lagier JC, Million M, Gautret P, Colson P, Cortaredona S, Raoult D. Outcomes of 3,737 COVID-19 patients treated with hydroxychloroquine/azithromycin and other regimens in Marseille, France: a retrospective analysis. Travel Medicine and Infectious Disease 2020.

121. Million $M$, Gautret $P$, Colson $P$, Roussel $Y$, Dubourg $G$, Raoult $D$. Clinical efficacy of chloroquine derivatives in COVID-19 infection: Comparative meta-analysis between big data and the real world. New Microbes and New Infections 2020.

122. Morgan A, Stevens J. Does Bacopa monnieri improve memoy performance in older persons? Results of a randomized, placebo-controlled, double-blind trial. J Altern Complement Med 2010; 16:753-9.

123. Effect of Dexamethasone in hospitalized patients with COVID-19-Preliminary report. N Engl J Med 2020.

124. Schultze A, Walker AJ, MacKenna B, Morten CE, Bhaskaran K, Brown JP. Inhaled corticosteroids use and the risk of COVID-19 related death among 966,461 patients with COPD or asthma: An OpenSAFELY analysis. medRxiv 2020.

125. Quesada-Gomez JJ, Bouillon R. Is calcifediol better than cholecalciferol for vitamin D supplementation? Osteoporosis International 2018; 29:1697-711.

126. Cesareo R, Falchetti A, Attanasio R, Tabacco G, Naciu AM. Hypovitaminosis D: Is it time to consider the use of calcifediol? Nutrients 2019; 11:1016. 
127. Early high-dose vitamin D3 for critically ill, vitamin D-deficient patients. N Engl J Med 2019; 381:2529-40.

128. Amrein K, Martucci G, McNAlly JD. When not to use meta-analysis: Analysing the meta-analysis on vitamin D in critical care. Clin Nutr 2017; 36:1729-30.

129. Zhang X, Song Y, Ci X, An N, Ju Y. Ivermectin inhibits LPS-induced production of inflammatory cytokines and improves LPS-induced survival in mice. Inflamm Res 2008; 57:524-9.

130. Ci X, Li H, Yu Q et al. Avermectin exerts anti-inflammatory effect by downregulating the nuclear transcription factor kappa-B and mitogen activated protein kinase pathway. Fundamental \& Clinical Pharmacology 2009; 23:449-55.

131. DiNicolantonio JJ, Barroso-Arranda J, McCarty M. Ivermectin may be a clinically useful anti-inflammatory agent for late-stage COVID-19. Open Heart 2020; 7:e001350.

132. Hsu A, Liu Y, Zayac AS, Olszewski AJ, Reagan JL. Intensity of anticoagulation and survival in patients hospitalized with COVID-19 pneumonia. Thrombosis Research 2020.

133. Kwon PS, Oh H, Kwon SJ et al. Sulphated polysaccharides effectively inhibit SARS-CoV-2 in vitro. Cell Discovery 2020; 6:50.

134. Bikdeli B, Madhavan MV, Jimenez, Chuich T, Dreyfus I. COVID-19 and thrombotic or thromboembolic disease: Implications for prevention, antithrombotic therapy, and follow-up. J Am Coll Cardiol 2020.

135. Connors JM, Levy JH. COVID-19 and its implications for thrombosis and anticoagulation. Blood 2020.

136. Nadkarni GN, Lala A, Bagiella E, Chang HL, Moreno P. Anticoagulation, mortality, bleeding and pathology among patients hospitalized with COVID-19: A single Health System Study. J Am Coll Cardiol 2020.

137. Klok FA, Kruip MJ, van der Meer NJ, Arbous MS. Incidence of thrombotic complications in critically ill ICU patients with COVID-19. Thrombosis Research 2020.

138. Zhai Z, Li C, Chen Y, Gerotziafas G, Zhang Z. Prevention and treatment of venous thromboembolism assocaited with Coronavirus Disease 2019 Infection: A consensus statement before guidelines. Thromb Haemost 2020.

139. Paranjpe I, Fuster V, Lala A, Russak A, Glicksberg BS. Association of treatment dose anticoagulation with in-hospital survival among hospitalized patietns with COVID-19. J Am Coll Cardiol 2020.

140. Iba T, Levy JH, Levi M, Connors JM. Coagulopathy of coronavirus disease 2019. Crit Care Med 2020.

141. Joly BS, Siguret V, Veyradier A. Understanding pathophysiology of hemostasis disorders in critically ill patients with COVID-19. Intensive Care Med 2020; 46:1603-6.

142. Helms J, Tacquard C, Severac F, Leonard-Lorant I, Ohana M. High risk of thrombosis in patients with severe SARS-CoV-2 infection: a multicenter prospective cohort study. Intensive Care Med 2020; 46:108998.

143. Varatharajah N, Rajah S. Microthrombotic complications of COVID-19 are likely due to embolism of circulating endothelial derived ultralarge Von Willebrand Factor (eULVWF) decorated-platelet strings. Federal Practitioner 2020.

144. Du L, Kao RY, Zhou Y, He Y. Cleavage of spike protein of SARS coronavirus by protease factor Xa is associated with viral infectivity. Biochemical \& Biophysical Research Communications 2007; 359:174-9.

145. Taccone FS, Gevenois PA, Peluso L, Pletchette Z, Lheureux O. Higher intensity thromboprophylaxis regimens and pulmonary embolism in critically ill coronavirus disease 2019 patients. Crit Care Med 2020.

146. Villar J, Confalonieri M, Pastores SM, Meduri GU. Rationale for prolonged corticosteroid tratment in the acute respiratory distress syndrome (ARDS) caused by COVID-19. Crit Care Expl 2020; 2:e0111.

147. Fadel R, Morrison AR, Vahia A et al. Early course corticosteroids in hospitalized patients with COVID-19. Clin Infect Dis 2020; 71:2114-20.

148. Chroboczek T, Lacoste M, Wackenheim C, Challan-Belval T, Amar B, Boisson T. Beneficial effect of corticosteroids in severe COVID-19 pneumonia: a propensity score matching analysis. medRxiv 2020.

149. Wu C, Chen X, Cai Y, Xia J, Zhou X, Xu S. Risk factors associated with acute respiratory distress syndrome and death in patients with Coronavirus disease 2019 pneumonia in Wuhan,China. JAMA Intern Med 2020.

150. Cruz AF, Ruiz-Antoran B, Gomez AM, Lopez AS. Impact of glucocorticoid treatment in SARS-CoV-2 infection mortality: A retrospective controlled cohort study. medRxiv 2020.

151. Liu J, Zheng X, Huang Y, Shan H, Huang J. Successful use of methylprednisolone for treating severe COVID19. J Allergy Clin Immunol 2020.

152. Meduri GU, Bridges L, Shih MC, Marik PE, Siemienluk RA, Kocak M. Prolonged glucocorticoid treatment is associated with improved ARDS outomces: analysis of individual patients' data from four randomized trials and trial-level meta-analysis of the updated literature. Intensive Care Med 2016; 42:829-40. 
153. Association between administration of systemic corticosteroids and mortality among critically ill patients with COVID-19. A meta-analysis. JAMA 2020.

154. Ruiz-Irastorza G, Pijoan JI, Bereciatua E, Dunder S, Dominguez J, Garcia-Escudero P. Second week methylprednisolone pulses improve prognosis in patients with severe coronavirus disease 2019 pneumonia: An observational comparative study using routine care data. medRxiv 2020.

155. Tomazini BM, Maia IS, Cavalcanti AB, Berwanger O, Rosa RG, Veiga VC. Effect of dexamethasone on days alive and ventilaor-free in patients with moderate or severe acute respiratory distress syndrome and COVID-19. The CoDEX randomized clinical trial. JAMA 2020.

156. Edalatifard M, Akhtari M, Salehi M, Naderi Z, Jamshidi A, Mostafaei S. Intravenous methylprednisolone pulse as a treatment for hospitalized severe COVID-19 patients: results from a randomised controlled clinical trial. Eur Respir J 2020.

157. Effect of hydrocortisone on mortality and organ support in patients with severe COVID-19. The REMAPCAP COVID-19 Corticosteroid Domain Randomized Clinical Trial. JAMA 2020.

158. Dequin PF, Heming N, Meziani F, Plantefeve G, Voiriot G. Effect of hydrocortisone on 21-day mortality or respiratory support among critically ill patients with COVID-19. A randomized Clinical trial. JAMA 2020.

159. Wang Y, Zhang D, Du G, Du R. Remdesivir in adults with severe COVID-19: a randomised, double-blind, placebo-controlled, multicenter trial. Lancet 2020; 395:1569-78.

160. Beigel JH, Tomashek KM, Dodd LE et al. Remdesivir for the treatment of Covid-19-Preliminary report. N Engl J Med 2020; ePub.

161. Spinner CD, Gottlieb RL, Criner GJ, Lopez JR, Cattelan AM. Effect of remdesivir vs standard care on clinical status at 11 days in patients with moderate COVID-19. A randomized clinical trial. JAMA 2020.

162. Pan H, Peto R, Karim QA, Alejandria M, Henao-Restrepo AM. Repurposed antiviral drugs for COVID-19 interim WHO SOLIDARITY trial. medrx 2020.

163. Marik PE, Kory P, Varon J, Iglesias J, Meduri GU. MATH+ protocol for the treatment of SARS-CoV-2 infection: the scientific rationale. Exp Rev Anti Infect Ther 2020.

164. Marik PE, Khangoora V, Rivera R, Hooper MH, Catravas J. Hydrocortisone, Vitamin C and Thiamine for the treatment of severe sepsis and septic shock: A retrospective before-after study. Chest 2017; 151:1229-38.

165. Barabutis N, Khangoora V, Marik PE, Catravas JD. Hydrocortisone and Ascorbic Acid synergistically protect and repair lipopolysaccharide-induced pulmonary endothelial barrier dysfunction. Chest 2017; 152:95462.

166. Marik PE. Hydrocortisone, Ascorbic Acid and Thiamine (HAT therapy) for the treatment of sepsis. Focus on ascorbic acid. Nutrients 2018; 10:1762.

167. Marik PE. Vitamin C for the treatment of sepsis: The scientific rationale. Pharmacol Therapeut 2018; 189:63-70.

168. Cheng RZ. Can early and high-dose vitamin C prevent and treat coronavirus disease 2019 (COVID-19). Medicine in Drug Discovery 2020.

169. Wang $Y$, Lin $H$, Lin BW, Lin JD. Effects of different ascorbic acid doses on the mortality of critically ill patients: a meta-analysis. Ann Intensive Care 2019; 9:58.

170. Fowler AA, Truwit JD, Hite D et al. Vitamin C Infusion for TReatment In Sepsis-Induced Acute Lung InjuryCITRIS-ALI: A Randomized, Placebo Controlled Clinical Trial. JAMA 2018; 322:1261-70.

171. Boretti A, Banik BK. Intravenous vitamin C for reduction of cytokines storm in acute respiratory distress syndrome. PharmaNutrition 2020; 12:100190.

172. Iglesias J, Vassallo AV, Patel V, Sullivan JB, Cavanaugh J, Elbaga Y. Outcomes of metabolic resuscitation using ascorbic acid, thiamine, and glucocorticoids in the early treatment of sepsis. Chest 2020; 158:16473.

173. de Melo AF, Homem-de-Mello M. High-dose intravenous vitamin C may help in cytokine storm in severe SARS-CoV-2 infection. Crit Care 2020; 24:500.

174. Zhang J, Rao X, Li Y et al. High-dose vitamin C infusion for the treatment of critically ill COVID-19. Research Square 2020.

175. Jonmarker S, Hollenberg J, Dahlberg M, Stackelberg O. Dosing of thromboprophylaxis and mortality in critically ill COVID-19 patients. medRxiv 2020.

176. Tomasa-Irriguible TM, Martinez-Vega S, Mor-Marco E, Herraiz-Ruiz A, Raguer-Pardo L. Low molecular weight heparins in COVID-19 patients: beware of augmented renal clearance! Crit Care 2020; 24:325.

177. Murshed MR, Bhiuyan E, Saber S, Alam RF, Robin RF. A case series of 100 COVID-19 positive patients treated with combination of Ivermectin and Doxycycline. Bangladesh Coll Phys Surg 2020; 38:10-5. 
178. Patel AN, Desai SS, Grainger DW, Mehra MR. Usefulness of ivermectin in COVID-19 illness. medRxiv 2020.

179. Jans DA, Wagstaff KM. Ivermectin as a broad-spectrum host directed anti-viral: The real deal. Cells 2020; 9:2100.

180. Sharun K, Dhama K, Patel SK, Pathak M, Tiwari R. Ivermectin, a new candidate therapeutic against SARSCoV-2/COVID-19. Ann Clin Microbiol Antimicrob 2020; 19:23.

181. Peralta EG, Fimia-Duarte R, Cardenas JW, Dominguez DV, Segura RB. Ivermectin, a drug to be considered for the prevention and treatment of SARS-CoV-2. Brief literature review. EC Veterinary Science 2020; 5:25-9.

182. Al-Jassim KB, Jawad AA, Al-Masoudi EA, Majeed SK. Histopathological and biochemical effects of ivermectin on kidney functions, lung and the ameliorative effects of vitamin $C$ in rabbits. Bas $J$ Vet Res 2016; 14:110-24.

183. Mudatsir M, Yufika A, Nainu F, Frediansyah A, Megawati D. Antiviral activity of ivermectin against SARSCoV-2: an old-fashioned dog with a new trick- Literature review. Sci Pharm 2020; 88:36.

184. Carvallo H, Hirsch R, Farinella ME. Safety and efficacy of the combined use of Ivermectin, dexamethasone, enoxaparin and aspirin against COVID-19. medRxiv 2020.

185. Menezes RR, Godin AM, Rodrigues FF, Coura GM, Melo IS, Brito AM. Thiamine and riboflavin inhibit production of cytokines and increase the anti-inflammatory activity of a corticosteroid in a chronic model of inflammation induced by complete Freund's adjuvant. Pharmacological Reports 2020; 69:1036-43.

186. Vatsalya V, Li F, Frimodig J, Gala KS, Srivastava S, Kong M. Therapeutic prospects for Th-17 cell immune storm syndrome and neurological symptoms in COVID-19: Thiamine efficacy and safety, In-vitro evidence and pharmacokinetic profile. medRxiv 2020.

187. Mallat J, Lemyze M, Thevenin D. Do not forget to give thiamine to your septic shock patient! J Thorac Dis 2016; 8:1062-6.

188. Moskowitz A, Donnino MW. Thiamine (vitamin B1) in septic shock: a targeted therapy. J Thorac Dis 2020; 12 (suppl 1):S78-S83.

189. Woolum JA, Abner EL, Kelly A, Thompson Bastin ML, Morris PE, Flannery AH. Effect of thiamine administration on lactate clearance and mortality in patients with septic shock. Crit Care Med 2018; 46:1747-52.

190. Marik PE. Thiamine: An essential component of the metabolic resuscitation protocol. Crit Care Med 2018; 46:1869-70.

191. Lee CY, Jan WC, Tsai PS, Huang CJ. Magnesium sulfate mitigates acute lung injury in endotoxemia rats. J Trauma 2011; 70:1177-85.

192. Salem M, Kasinski N, Munoz R, Chernow B. Progressive magnesium deficiency inceases mortality from endotoxin challenge:Protective effects of acute magnesium replacement therapy [abstract]. Crit Care Med 1995;A260.

193. Jiang P. Does hypomagnesemia impact on the outcome of patients admitted to the intensive care unit? $A$ systematic review and meta-analysis. Shock 2019; 47:288-95.

194. Lenze EJ, Mattar C, Zorumski CF, Stevens A, Nicol GE, Miller JP. Fluvoxamine vs placebo and clinical deterioration in outpatietns with symptomatic COVID-19. A randomized clinical trial. JAMA 2020.

195. Zimering MB, razzaki T, Tsang T, Shin JJ. Inverse association between serotonin $2 A$ receptor antaagonist medication use and mortality in severe COVID-19 infection. Endocrinol Diabetes Metab J 2020; 4:1-5.

196. Calfee CS, Delucchi KL, Sinha P, Matthay MA, Hackett J, Shankar-Hari M. Acute respiratory distress syndrome subphenotypes and differential response to simvastatin: secondary analysis of a randomised controlled trial. Lancet Resp Med 2018; 6:691-8.

197. Zhang XJ, Qin JJ, Cheng X et al. In-hospital use of statins is associated with a reduced risk of mortality among individuals with COVID-19. Cell Metabolism 2020.

198. Rodriguez-Nava G, Trelles-Garcia DP, Yanez-Bello MA, Chung CW. Atorvastatin associated with decreased hazard for death in COVID-19 patients admitted to an ICU: a retrospective cohort study. Crit Care 2020; 24:429.

199. Gupta A, Madhavan MV, Poterucha TJ, DeFilippis EM, Hennessey JA. Association between antecedent statin use and decreased mortality in hospitalized patients with COVID-19. Research Square 2020.

200. Kow CS, Hasan SS. Meta-analysis of effectiveness of statins in patients with severe COVID-19. Am J Cardiol 2020.

201. Tan WY, Young BE, Lye DC, Chew DE, Dalan r. Statin use is assocaited with lower disease severity in COVID-19 infection. Nature Research 2020. 
202. Oldenburg CE, Doan T. Azithromycin for severe COVID-19. Lancet 2020.

203. Futado RH, Berwanger O, Fonseca HA, Correa TD, Ferraz LR, Lapa MG. Azithromycin in addition to standard of care versus standard of care alone in the treatment of patients admitted to the hospital with severe COVID-19 in Brazil (COALITION II): a randomised trial. Lancet 2020.

204. Agarwal A, Mukherjee A, Kumar G, Chatterjee P, Bhatnager T. Convalescent plasma in the management of moderate covid-19 in adults in India: open label phase II multicentre randomised controlled trial (PLACID Trial). BMJ 2020; 371:m3939.

205. Simonovich VA, Pratx LD, Scibona P, Beruto MV, Vallone MG. A randomized trial of convalescent plasma in COVID-19 severe pneumonia. N Engl J Med 2020.

206. Rosas IO, Brau N, Waters M et al. Tocilizumab in hospitalized patients with COVID-19 pneumonia. medRxiv 2020.

207. Hermine $\mathrm{O}$, Mariette $\mathrm{X}$, Tharaux $\mathrm{PL}$, Resche-Rignon $\mathrm{M}$, Porcher $\mathrm{R}$. Effect of tocilizumab vs usual care in adults hospitalized with COVID-19 and moderate or severe pneumonia.A randomized Clinical Trial. JAMA Intern Med 2020.

208. Stone JH, Frigault MJ, Sterling-Boyd NJ, Fernandes AD, Harvey FL. Efficacy of tocilizumab in patients hospitalized with Covid-19. N Engl J Med 2020.

209. Salvarani C, Dolci G, Massari M, Merlo DF, Cavuto S. Effect of tocilizumab vs standard care on clinical worsening in patients hospitalized with COVID-19 pneumonia. A randomized clinical trial. JAMA Intern Med 2020.

210. Bassetti M, Kollef MH, Timsit JF. Bacterial and fungal superinfections in critically ill patients with COVID19. Intensive Care Med 2020.

211. Xu Q, Wang T, Quin X, Zha L. Early awake prone position combined with high-flow nasal oxygen therapy in severe COVID-19; a case series. Crit Care 2020; 24:250.

212. Elharrar X, Trigui Y, Dois AM, Touchon F. Use of prone positioning in nonintubated patients with COVID-19 and hypoxemic acute respiratory failure. JAMA 2020.

213. Keith P, Day M, Perkins L, Moyer L, Hewitt K, Wells A. A novel treatment approach to the novel coronavirus: an argument for the use of therapeutic plasma exchange for fulminant COVID-19. Crit Care 2020.

214. Keith $\mathrm{P}$, Wells $\mathrm{AH}$, Hodges J, Fast $\mathrm{SH}$. The therapeutic efficacy of adjunct therapeutic plasma exchange for septic shock with multiple organ failure: A single center experience. Crit Care 2020; 24:518.

215. Busund R, Koukline V, Utrobin U, Nedashkovsky E. Plasmapheresis in severe sepsis and septic shock: a prospective, randomised, controlled trial. Intensive Care Med 2002; 28:1434-9.

216. Morath C, Weigand MA, Zeier M, Speer C, Tiwari-Heckler S. Plasma exchange in critically ill COVID-19 patients. Crit Care 2020; 24:481.

217. Khamis F, Al-Zakwani I, Al Hashmi S, Al Dowaiki S, Al Bahrani M. Therapeutic plasma exchange in adults with severe COVID-19 infection. Int J Infect DIs 2020.

218. Fernandez J, Gratacos-Gines J, Olivas P, Costa M, Nieto S, Mateo D. Plasma exchange: An effective rescue therapy in critically ill patients with Coronavirus Disease 2019 infection. Crit Care Med 2020.

219. Gucyetmez B, Atalan HK, Sertdemir I, Cakir U, Telci L. Therapeutic plasma exchange in patients with COVID-19 pneumonia in intensive care unit: a retrospective study. Crit Care 2020; 24:492.

220. Poor HD, Ventetuolo CE, Tolbert T, Chun G, Serrao G. COVID-19 critical illness pathophysiology driven by diffuse pulmonary thrombi and pulmonary endothelial dysfuncion responsive to thrombolysis. medRxiv 2020.

221. Wang J, Najizadeh N, Moore EE, McIntyre RC, Moore PK, Veress LA. Tissue plasminogen activator (tPA) treatment for COVID-19 associated respiratory distress syndrome (ARDS): A case series. J Thromb Haemost 2020.

222. Henry MB, Lippi G. Poor survival with extracorporeal membrane oxygenation in acute respiratory distress syndrome (ARDS) due to coronavirus disease 2019 (COVID-19): Pooled analysis of early reports. J Crit Care 2020; 58:27-8.

223. Abrams D, Lorusso R, Vincent JL, Brodie D. ECMO during the COVID-19 pandemic: when is it unjustified. Crit Care 2020; 24:507.

224. Barbaro RP, MacLaren G, Boonstra PS, Iwashyna TJ, Slutsky AS. Extracorporeal membrane oxygenation support in COVID-19: an international cohort study of the Extracorporeal Life Support Organization registry. Lancet 2020. 
225. Abou-Arab O, Huette P, Debouvries F, Dupont $H$, Jounieaux V. Inhaled nitric oxide for critically ill Covid-19 patients: a prospective study. Crit Care 2020; 24:645.

226. Bagate F, Tuffet $S$, Masi P, Perier F, Razazi K. Rescue thearpy with inhaled nitric oxide and almitrine in COVID-19 patients with severe acute respiratory distress syndrome. Ann Intensive Care 2020.

227. Caplan M, Goutay J, Bignon A, Jaillette E, Favory R. Almitrine infusion in severe acute respiratory syndrome coronavirus- 2 indued acute respiratory distress syndrome: A single-center observational study. Crit Care Med 2020.

228. Payen D. Coronavirus disease 2019 acute respiratory failure: Almitrine drug resuscitaion or resuscitating patients by almitrine? Crit Care Med 2020.

229. Zeng QL, Yu ZJ, Gou JJ, Li GM. Effect of convalescent plasma therapy on viral shedding and survival in COVID-19 patients. Clin Infect Dis 2020.

230. Li L, Zhang W, Hu Y, Tong X, Zeng S, Yang J. Effect of convalescent plasma therapy on time to clinical improvement in patients with severe and life-threatening COVID-19. A randomized clinical trial. JAMA 2020; 324:460-70.

231. Fleming AB, Raabe V. Current studies of convalescent plasma therapy for COVID-19 may underestimate risk of antibody-dependent enhancement [letter]. J Clin Virol 2020; 127:104388.

232. Duan K, Liu B, Li C, Zhang H. Effectiveness of convalescent plasma therapy in severe COVID-10 patients. PNAS 2020.

233. Cerutti A, Chen K, Chorny A. Immunoglobulin responses at the mucosal interface. Annu Rev Immunol 2011; 29:273-93.

234. Jacobs JJ. Neutralizing antibodies mediate virus-immue pathology of COVID-19. Med Hypotheses 2020; 143:109884.

235. Wu D, Yang XO. TH17 responses in cytokine storm of COVID-19: An emerging target of JAK2 inhibitor Febratinib. J Microbiol Immunol Infect 2020.

236. Favalli EG, Biggioggero M, Maioli G, Caporali R. Baricitinib for COVID-19: a suitable treatment? Lancet Infect Dis 2020.

237. Mehta P, McAuley DF, Brown M, Sanchez E, Tattersall RS, Manson JJ. COVID-19: consider cytokine storm syndromes and immunosuppression. Lancet 2020; 395:1033-4.

238. Seifirad S. Pirfenidone: A novel hypothetical treatment for COVID-19. Medical Hypotheses 2020; 144:11005.

239. Saba A, Vaidya PJ, Chavhan VB, Achlerkar A, Leuppi J. Combined pirfenidone, azithromycin and prednisolone in post-H1N1 ARDS pulmonary firbosis. Sarcoidosis Vasc Diffuse Lung Dis 2018; 35:85-90.

240. Spagnolo P, Balestro E, Aliberti S, Cocconcelli E, Biondini D, Casa GD. Pulmonary fibrosis secondary to COVID-19: a call to arms? Lancet Resp Med 2020; 8:750-2.

241. George PM, Wells AU, Jenkins RG. Pulmonary fibrosis and COVID-19: the potential role for antibibrotic therapy. Lancet Resp Med 2020; 8:807-15.

242. Brouwer WP, Duran S, Kuijper M, Inc C. Hemoadsorption with CytoSorb shows a decreased observed versus expected 28-day all-cause mortality in ICU patients with septic shock: a propensity-score-weighted retrospective study. Crit Care 2019; 23:317.

243. Villa G, Romagnoli S, De Rosa S, Greco M, Resta M. Blood purification therapy with a hemodiafilter featuring enhanced adsorptive properties for cytokine removal in patients presenting COVID-19: a pilot study. Crit Care 2020; 24:605.

244. Bryce C, Grimes Z, Pujadas E et al. Pathopysiology of SARS-CoV-2: targeting of endothelial cells renders a complex disease with thrombotic microangiopathy and aberrant immune response. The Mount Sinai COVID-19 autopsy experience. medRxiv 2020.

245. Slaats J, ten Oever J, van de Veerdonk FL, Netea MG. II-1B/II-6/CRP and IL-18/ferritin: Distinct inflammatory programs in infections. PLos Pathog 2016; 12:e1005973.

246. Colafrancesco S, Alessandri C, Conti F, Priori R. COVID-19 gone bad: A new character in the spectrum of the hyperferritinemic syndrome? Autoimmunity Reviews 2020; 19:102573.

247. Giamarellos-Bouboulis EJ, Netea MG, Rovina $\mathrm{N}$ et al. Complex immune dysregulation in COVID-19 patients with severe respiratory failure. Cell Host \& Microbe 2020.

248. McGonagle D, Sharif K. The role of cytokines including interleukin-6 in COVID-19 induces pneumonia and macrophage activation syndrome-like disease. Autoimmunity Reviews 2020. 
249. Kyriazopoulou E, Leventogiannis K, Norrby-Teglund A, Dimopoulos G. Macrophage activation-like syndrome: an immunological entity associated with rapid progression to death in sepsis. BMC Medicine 2017; 15:172.

250. Tan C, Huang Y, Shi F, Tan K, Ma Q, Chen Y. C-reactive protein correlates with computed tomographic findings and predicts severe COVID-19 early. J Med Virol 2020; 92:856-62.

251. Howell AP, Parrett JL, Malcom DR. Impact of high-dose intravenous vitamin C for treatment of sepsis on point-of-care blood glucose readings. J Diabetes Sci Technol 2019.

252. Stephenson E, Hooper MH, Marik PE. Vitamin C and Point of Care glucose measurements: A retrospective, Observational study [Abstract]. Chest 2018; 154 (suppl.):255a.

253. Brosnahan SB, Bhatt A, Berger JS, Yuriditsky E, Iturrate E. COVID-19 pneumonia hospitalizations followed by re-presentation for presumed thrombotic event. Chest 2020.

254. Spyropoulos AC, Lipardi C, XU J, Peluso C, Spiro TE. Modified IMPROVE VTE Risk Score and elevated DDimer identify a high venous thromboembolism risk in acutely ill medical population for extended thromboprophylaxis. TH Open 2020; 4:e59-e65.

255. Kunutsor SK, Seidu S, Blom AW, Khunti K. Serum C-reactive protein increases the risk of venous thromboembolism: a prospective study and meta-analysis of published prospective evidence. Eur J Epidemiol 2017; 32:657-67.

256. Carfi A, Bernabei R, Landi F. Persistent symptoms in patients after acute COVID-19. JAMA 2020.

257. Prescott HC, Girard TD. Recovery from Severe COVID-19. Leveraging the lessons of survival from sepsis. JAMA 2020.

258. Greenhalgh T, Knight M, A'Court C, Buxton M, Husain L. Management of post-acute Covid-19 in primary care. BMJ 2020.

259. Lu Y, Li X, Geng D, Mei N, Wu PY, Huang CC. Cerebral micro-structutal changes in COVID-19 patients - An MRI-based 3-month follow-up study. EClinicalMedicine 2020.

260. Riche F. Protracted immune disorders at one year after ICU discharge in patients with septic shock. Crit Care 2018; 22:42.

261. Andreakos E, Papadaki M, Serhan CN. Dexamethasone, pro-resolving lipid mediators and resolution of inflammation in COVID-19. Allergy 2020.

262. Dalli J, Chiang N, Serhan CN. Elucidation of novel 13-series resolvins that increase with atorvastatin and clear infections. Nat Med 2015; 21:1071-5.

263. Aguirre-Chang G, Castillo Saavedra E, Yui Cerna M, Trugjillo Figuerdo A. Post-acute or prolonged COVID19: Treatment with ivermectin for patients with persistent, or post-acute symptoms. Research Square 2020.

264. Gao J, Zheng P, Jia Y, Chen H. Mental health problems and social media exposure during COVID-19 outbreak. PloS ONE 2020; 15:e0231924.

265. Pennycook G, McPhetres J, Zhang Y, Lu JG, Rand DG. Fighting COVID-19 misinformation on Social Media: Experimental Evidence fo a Scalable Accuracy-Nudge Intervention. Psychological Science 2020; 31:770-80.

266. Kurcicka L, Lauer SA, Laeyendecker O, Boon D, Lessler J. Variation in false-negative rate of reverse transcriptase polmerase chain reacion-based SARS-CoV-2 tests by time since exposure. Ann Intern Med 2020; 173:262-7.

267. Cheng HY, Jian SW, Liu DP, Huang WT, Lin HH. Contact tracing assessment of COVI-19 transmission dynamics in Taiwan and risk at different exposure periods before and after symptom onset. JAMA Intern Med 2020; 180:1156-63.

268. Zhao J, Yang Y, Huang H, Li D, Gu D. Relationship between ABO blood group and the COVID-19 susceptibility. medRxiv 2020.

269. Banerjee A, Pasea L, Harris S, Gonzalez-Izquierdo A. Estimating excess 1-year mortality associated with the COVID-19 pandemic according to underlying conditions and age: a population-based cohort study. Lancet 2020; 395:1715-25.

270. Goren A, Vamo-Galvan S, Wambier CG, McCoy J. A preliminary observation: Male pattern hair loss among hospitalized COVID-19 patients in Spain- A potential clue to the role of androgens in COVID-19 severity. J Cosmetic Dermatol 2020.

271. Huang C, Wang Y, Li X et al. Clinical features of patients infected with 2019 novel coronavirus in Wuhan,China. Lancet 2020; 395:497-506.

272. Guan W, Ni Z, Hu Y, Liang W, Ou C, He J. Clinical characteristics of Coronavirus disease 2019 in China. N Engl J Med 2020. 
273. von der Thusen J, van der Eerden M. Histopathology and genetic susceptibility in COVID-19 pneumonia. Eur J Clin Invest 2020.

274. Sweeney TE, Liesenfeld O, Wacker J, He YD, rawling D, Remmel M. Validation of inflammopathic, adaptive, and coagulopathic sepsis endotypes in Coronavirus disease 2019. Crit Care Med 2020.

275. Tartof SY, Qian L, Hong V, Wei R, Nadjafi RF, Fischer H. Obesity and mortality among patients diagnosed with COVID-19: Results from an integrated health care organization. Ann Intern Med 2020.

276. Pujadas E, Chaudhry F, McBride R, Richter F, Zhao S. SARS-CoV-2 viral load predictes COVID-19 mortality. Lancet Resp Med 2020.

277. Akbar AN, Gilroy DW. Aging immunity may exacerbate COVID-19. Science 2020; 369.

278. Zhang Q, Bastard P, Liu Z, Le Pen J, Chen J, Korol C. Inborn errors of type I IFN immunity in patients with life-threatening COVID-19. Science 2020.

279. Zhou Y, Fu B, Zheng $X$, Wang D, Zhao C. Pathogenic T cellls and inflammatory monocytes incite inflammatory storm in severe COVID-19 patients. Natl Sci Rev 2020; 7:998-1002.

280. Blanco-Melo D, Nilsson-Payant BE, Liu WC, Uhl S. Imbalanced host response to SARS-CoV-2 drives development of COVID-19. Cell 2020.

281. Zhou F, Yu T, Du R, Fan G, Liu Y, Liu Z. Clinical course and risk factor for mortality of adult inpatients with COVID-19 in Wuhan, China: a retrospective cohort study. Lancet 2020.

282. Giamarellos-Bourboulis EJ, Netea MG, Rovina N, Akinosoglou K. Complex immune dysregulation in COVID19 patients with severe respiratory failure. medRxiv 2020.

283. Qin C, Zhou L, Hu Z, Zhang S. Dysregulation of the immune response in patiens with COID-19 in Wuhan, China. Lancet Infect Dis 2020.

284. Zhang C, Wu Z, Li JW, Zhao H, Wang GQ. The cytokine release syndrome (CRS) of severe COVID-19 and interleukin-6 receptor (IL-6R) antagonsit Tocilizumab may be the key to reduce the mortality. Int J Antimicrob Agents 2020.

285. Ye Q, Wang B, Mao J. The pathogenesis and treatment of the "Cytokine Storm" in COVID-19. J Infection 2020.

286. Moore JB, June CH. Cytokine release syndrome in severe COVID-19. Science 2020.

287. Tay MZ, Poh CM, Renia L, MacAry PA. The trinity of COVID-19: immunity, inflammation and intervention. Nature Reviews 2020; 20:363-74.

288. Leisman DE, Deutschman CS, Legrand M. Facing COVID-19 in the ICU: vascular dysfunction, thrombosis, and dysregulated inflammation. Intensive Care Med 2020; 46:1105-8.

289. Teuwen LA, Geldhof V, Pasut A, Carmeliet P. COVID-19: the vasculature unleashed. Nature Reviews 2020.

290. Varga Z, Flammer AJ, Steiger P, Habrecker M, Andermatt R, Zinkernagel AS. Endothelial cell infection and endotheliitis in COVID-19. Lancet 2020.

291. Ackermann M, Verleden SE, Kuehnel M, Haverich A, Welte T. Pulmonary vascular endothelialitis, Thrombosis, and Angiogenesis in COVID-19. N Engl J Med 2020; 383:120-8.

292. Kory P, Kanne JP. SARS-CoV-2 organizing pneumonia:"Has there been a widespread failure to identify and treat this prevalent condition in COVID-19?'. BMJ Open Resp Res 2020; 7:e000724.

293. Torrealba JR, Fisher S, Kanne JP, Butt YM, Glazer C, Kershaw C. Pathology-radiology correlation of common and uncommon computed tomographic patterns of organizing pneumonia. Human Pathology 2018; 71:30-40.

294. Kanne JP, Little BP, Chung JH, Elicker BM. Essentials for radiologists on COVID-19: an Update-Radiology Scientific Expert Panel. Radiology 2020.

295. Copin MC, Parmentier E, Duburcq T, Poissy J, Mathieu D. Time to consider histologic pattern of lung injury to treat critically ill patietns with COVID-19 infection [letter]. Intensive Care Med 2020.

296. Gattinoni L, Chiumello D, Caironi P, Busana M, Romitti F, Brazzi L. COVID-19 pneumonia: different respiratory treatment for different phenotypes? Intensive Care Med 2020; 46:1099-102.

297. Chiumello D, Cressoni M, Gattinoni L. Covid-19 does not lead to a "typical" Acute Respiratory Distress syndrome. Lancet 2020.

298. Gattinoni L, Chiumello D, Rossi S. COVID-19 pneumonia: ARDS or not? Crit Care 2020; 24:154.

299. Gattinoni L, Pesenti A. The concept of "baby lung". Intensive Care Med 2005; 31:776-84.

300. Jeronimo CM, Farias ME, Almeida FF, Sampaio VS, Alexandre MA, Melo GC. Methylprednisolone as adjunctive therapy for patients hospitalized with COVID-19 (Metcovid): A ramdomised, double-blind, phase Ilb, placebo-controlled trial. Clin Infect Dis 2020. 
301. Carsana L, Sonzogni A, Nasr A, Rossi RS, Pellegrinelli A, Zerbi P. Pulmonary post-mortem findings in a large series of COVID-19 cases from Northern Italy. medRxiv 2020.

302. Menter T, Haslbauer JD, Nienhold R, Savic S, Hopfer H. Post-mortem examination of COVID19 patients reveals diffuse alveolar damage with severe capillary congestion and variegated findings of lungs and other organs suggesting vascular dysfunction. medRxiv 2020.

303. Xu Z, Shi L, Wang Y, Zhang J, Huang L, Zhang C. Pathological findings of COVID-19 associated with acute respiratory distress syndrome. Lancet Resp Med 2020.

304. Tobin MJ, Laghi F, Jubran A. Why COVID-19 silent hypoxemia is baffling to physicians. Am J Respir Crit Care Med 2020.

305. Schurink B, Roos E, Radonic T, Barbe E, Bouman CS. Viral presence and immunopathology in patients with lethal COVID-19: a prospective autopsy cohort study. Lancet Microbe 2020.

306. Buijsers B, Yanginlar C, Maciej-Hulme ML, de Mast Q. Beneficial non-anticoagulant mechanisms underlying heparin treatment of COVID-19 patients. EBioMedicine 2020.

307. Kim SY, Jin W, Sood A, Montgomery DW, Grant OC, Fuster MM. Characterization of heparin and severe acute respiratory syndrome-related coronavirus 2 (SARS-CoV-2) spike glycoprotein binding interactions. Antiviral Res 2020; 181:104873.

308. Clausen TM, Sandoval DR, Spliid CB et al. SARS-CoV-2 infection depends on cellular heparan sulphate and ACE2. bioRxiv 2020.

309. Huang $\mathrm{X}$, Han S, Liu $x$, Wang $\mathrm{T}, \mathrm{Xu} \mathrm{H}$. Both UFH and NAH alleviate shedding of endothelial glycocalyx and coagulopathy in LPS-induced sepsis. Exp Thera Med 2020; 19:913-22.

310. Buijsers B, Yanginlar C, de Nooijer A, Grondman I, Jonkman I, Rother N. Increased plasma heparanase activity in COVID-19 patients. medRxiv 2020.

311. May JM, Qu ZC. Ascorbic acid prevents oxidant-induced increases in endothelial permeability. Biofactors 2011; 37:46-50.

312. Utoguchi N, Ikeda K, Saeki K et al. Ascorbic acid stimulates barrier function of cultured endothelial cell monolayer. Journal of Cellular Physiology 1995; 163:393-9.

313. Han M, Pendem S, Teh SL, Sukumaran DK, Wu F, Wilson JX. Ascorbate protects endothelial barrier function during septic insult: Role of protein phosphatase type 2A. Free Radic Biol Med 2010; 48:128-35.

314. Elenkov IJ. Glucocorticoids and the Th1/Th2 balance. Ann N Y Acad Sci 2004; 1024:138-46.

315. Shodell M, Siegal FP. Corticosteroids depress INF-alpha-producing plasmacytoid dentritic cells in human blood. J Allergy Clin Immunol 2001; 108:446-8.

316. Thomas BJ, Porritt RA, Hertzog PJ, Bardin PG. Glucocorticosteroids enhance replication of respiratory viruses: effect of adjuvant interferon. Scientific Reports 2014; 4:7176.

317. Singanayagam A, Glanville N, Girkin JL, Ching YM, Marcellini A. Corticosteroid suppression of antiviral immunity increases bacterial loads and mucus production in COPD exacerbations. Nature Communications 2018; 9:2229.

318. Salton F, Confalonieri P, Santus P et al. Prolonged low-dose methylprednisolone in patients with severe COVID-19 pneumonia. medRxiv 2020.

319. Braude AC, Rebuck AS. Prednisone and methylprednisolone disposition in the lung. Lancet 1983;995-7.

320. Draghici S, Nguyen TM, Sonna LA et al. COVID-19: disease pathways and gene expression chnages predict methylprednisolone can improve outcome in severe cases. Nature Reviews 2020.

321. Chen L, Li J, Luo C, Liu H, Xu W, Chen G. Binding interaction of quercetin-3-B-galactoside and its synthetic derivatives with SARS-CoV 3CLpro: Structure-activity relationship studies revela salient pharmacophore features. Bioorganic \& Medicinal Chemistry 2020; 14:8295-306.

322. Ono K, Nakane H. Mechanisms of inhibition of various cellular DNA and RNA polymerases by several flavonoids. J Biochem 1990; 108:609-13.

323. Kaul TN, Middleton E, Pgra PL. Antiviral effects of flavonoids on human viruses. J Med Virol 1985; 15:71-9.

324. Shinozka K, Kikuchi Y, Nishino C, Mori A, Tawata S. Inhibitory effect of flavonoids on DNA-dependent DNA and RNA polymerases. Experientia 1988; 44:882-5.

325. Martin JH, Crotty S, Warren P. Does an apple a day keep the doctor away because a phytoestrogen a day keeps the virus at bay? A review of the anti-viral properties of phytoestrogens. Phytochemistry 2007; 68:266-74.

326. Smith M, Smith JC. Repurposing therapeutics for COVID-19: Supercomputer-based docking to the SARSCoV-2 viral spike protein and viral spike protein-human ACE2 interface. ChemRxiv 2020. 
327. Leyva-Lopez N, Gutierrez-Grijalva EP, Ambriz-Perez D. Flavonoids as cytokine modulators: A possible therapy for inflammation-related diseases. Int J Mol Sci 2016; 17:921.

328. Nair MP, Kandaswami C, Mahajan S, Chadha KC, Chawda R, Nair H. The flavonoid, quercetin, differentially regulates Th-1 (INF) and Th-2 (IL4) cytokine gene expression by normal peripheral blood mononuclear cells. Biochimica et Biophysica Acta 2020; 1593:29-36.

329. Dabbagh-Bazarbachi H, Clergeaud G, Quesada IM, Ortiz M, O'Sullivan CK. Zinc ionophore activity of Quercetin and Epigallocatechin-gallate:From Hepa 1-6 cells to a liposome model. J Agric Food Chem 2014; 62:8085-93.

330. Rhodes J, Dunstan F, Laird E, Subramanian S, Kenny RA. COVID-19 mortality inceases with northerly latitude after adjustment for age suggesting a link with ultraviolet and vitamin D. BMJ Nutrition, Prevenion \& Health 2020.

331. Tang N, Bai H, Chen X, Gong J, Li D, Sun Z. Anticoagulant treatment is associated with decreased mortality in severe coronavirus disease 2019 with coagulopathy. medRxiv 2020.

332. Sardu C, Gambardella J, Morelli MB, Wang X. Is COVID-19 an endothelial disease? Clinical and basic evidence. medRxiv 2020.

333. World Health Organization: Coronavirus Disease 2019 (COVID-19): Situation Report -54 (14th March 2020). https://www.who.int/docs/default-source/coronaviruse/situation-reports/20200314-sitrep-54covid-19.pdf . 2020. 7-9-2020.

334. Clinical management of COVID-19. Interim guidance. 27th May 2020. https://www.who.int/publications/i/item/clinical-management-of-covid-19 WHO/2019$\mathrm{nCoV/clinical/2020.5} \mathrm{.} \mathrm{2020.} \mathrm{World} \mathrm{Health} \mathrm{Organization.} \mathrm{7-10-2020.}$

335. Yam LY, Lau AC, Lai FY, Shung E, Chan J. Corticosteroid treatment of severe acute respiratory syndrome in Hong Kong. J Infection 2007; 54:28-39.

336. Siemieniuk RA, Bortoszko JJ, Ge L, Zeraatkar D, Izcovich A. Drug treatments for Covid-19: living systematic review and network meta-analysis. BMJ 2020.

337. Saune PM, Bryce-Alberti M, Portmann-Baracco AS, Accinelli RA. Methylprednisolone pulse therapy: An alternative management of severe COVID-19. Respiratory Medicine Case Reports 2020; 31:101221.

338. Fernandez-Cruz A, Ruiz-Antoran B, Gomez AM et al. Impact of glucocorticocoid treatment in SARS-CoV-2 infection mortality: A retrospective controlled cohort study. medRxiv 2020.

339. Corral-Gudino L, Bahamonde A, Arnaiz-Revillas F et al. GLUCOCOVID: A controlled trial of methylprednisolone in adults hospitalized with COVID-19 pneumonia. medRxiv 2020.

340. Stauffer WM, Alpern JD, Walker PF. COVID-19 and dexamethasone. A potential strategy to avoid steroidrelated Strongyloides hyperinfection. JAMA 2020; 324:623-4. 
Término da reprodução de conteudo An overview of the MATH+ and I-MASK+ Protocols 